\title{
AS MULHERES NO CÁRCERE: \\ GRAVIDEZ, MATERNIDADE E OS \\ DIREITOS DA PRISÃO DOMICILIAR
}

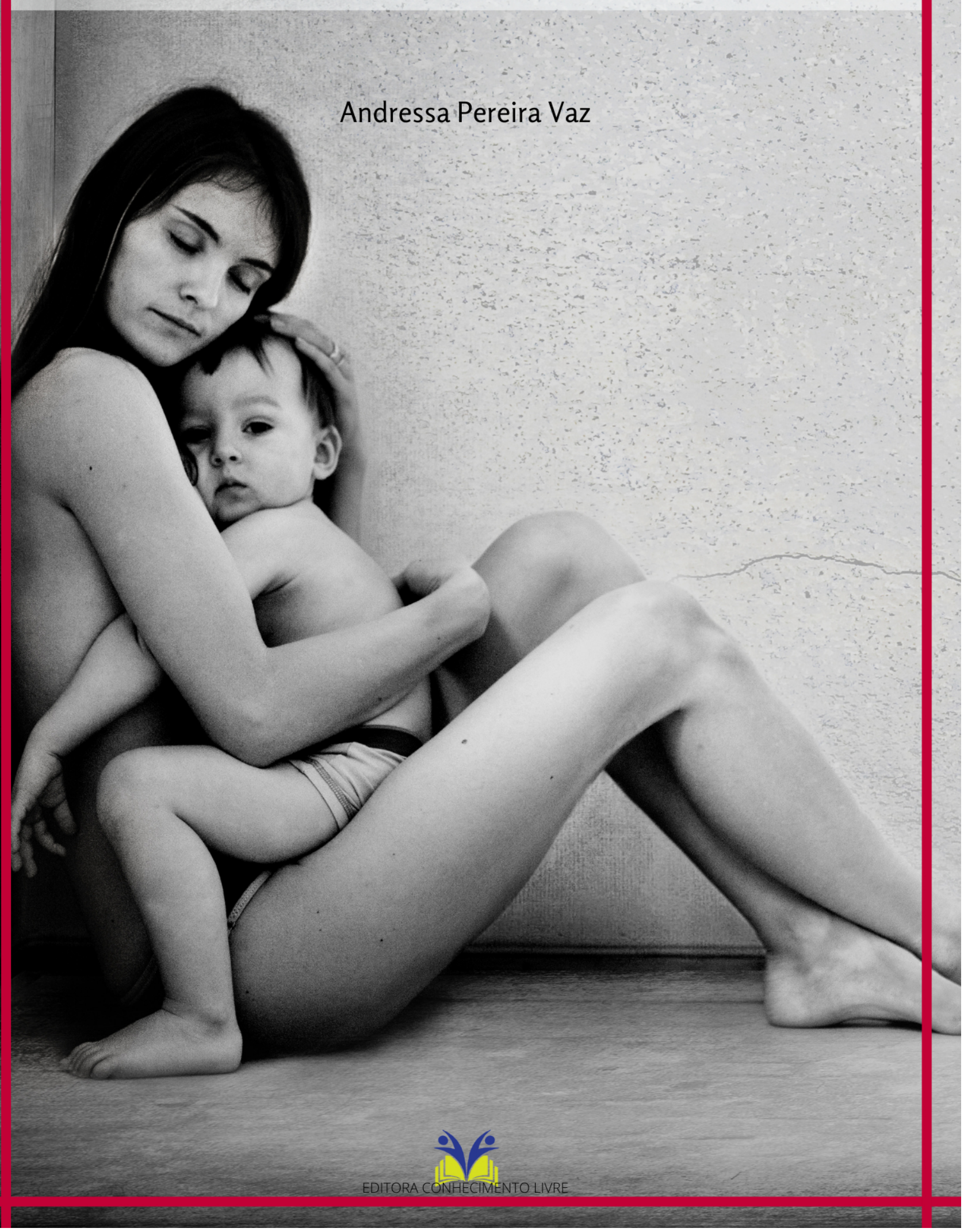


Andressa Pereira Vaz

As mulheres no cárcere: gravidez, maternidade e os direitos da prisão domiciliar

$1^{\text {a }}$ ed.

Piracanjuba-GO

Editora Conhecimento Livre

Piracanjuba-GO 
$1^{\mathrm{a}} \mathrm{ed}$

\section{Dados Internacionais de Catalogação na Publicação (CIP)}

Vaz, Andressa Pereira

V393A As mulheres no cárcere: gravidez, maternidade e os direitos da prisão domiciliar / Andressa Pereira Vaz. - Piracanjuba-GO

Editora Conhecimento Livre, 2021

$64 \mathrm{f.:}$ il

DOI: $10.37423 / 2021 . e d c l 285$

ISBN: 978-65-89955-16-0

Modo de acesso: World Wide Web

Incluir Bibliografia

1. mulheres 2. carcere 3. prisãodomiciliar I. Vaz, Andressa Pereira II. Título

https://doi.org/10.37423/2021.edc1285

O conteúdo dos artigos e sua correção ortográfica são de responsabilidade exclusiva dos seus respectivos autores. 


\title{
EDITORA CONHECIMENTO LIVRE
}

\section{Corpo Editorial}

\author{
Dr. João Luís Ribeiro Ulhôa \\ Dra. Eyde Cristianne Saraiva-Bonatto \\ Dr. Anderson Reis de Sousa \\ MSc. Frederico Celestino Barbosa \\ MSc. Carlos Eduardo de Oliveira Gontijo
}

$\underline{\text { MSc. Plínio Ferreira Pires }}$

Editora Conhecimento Livre

Piracanjuba-GO 
As mulheres no cárcere: gravidez, maternidade e os direitos da prisão domiciliar

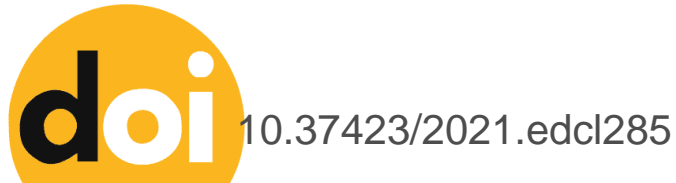

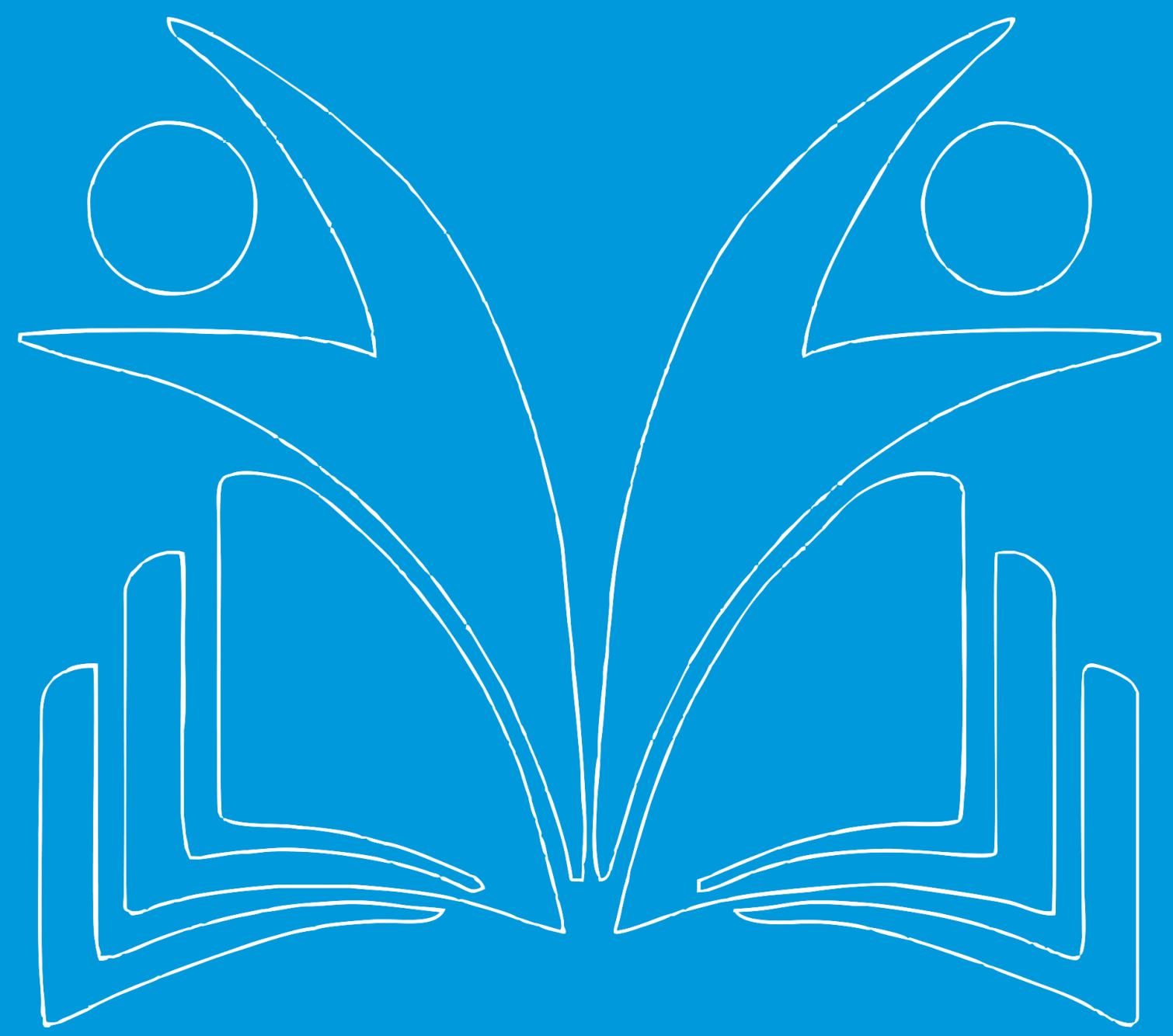


Resumo: A composição do artigo relata sobre as condições das mulheres gestantes e mães encarceradas nas instituições penitenciárias do Brasil. O presente estudo tem como tema as mulheres no cárcere: gravidez, maternidade e os direitos da prisão domiciliar. E traz como problemática quais os direitos das gestantes e mães encarceradas no sistema jurídico brasileiro? E como hipótese muitos autores discorrem sobre os direitos das detentas grávidas e mães nos presídios e afirmam que há muito a esclarecer sobre esses direitos e que muitas vezes são negados as detentas. Tem como objetivo geral elucidar as condições da maternidade nas penitenciárias. Além disso, foram estabelecidos como objetivos específicos: apresentar aspectos históricos da proteção constitucional da maternidade e também na atualidade; relatar sobre a realidade do sistema prisional; descrever sobre a gravidez e maternidade no cárcere e a prisão domiciliar. Para tal, este estudo efetivou-se através de uma revisão bibliográfica. Justifica-se tal pesquisa por razão de tantas polêmicas voltadas sobre o cárcere feminino inclusive quando envolve mães e seus filhos na prisão. Após a efetivação da análise dos dados, pôde-se constatar que os direitos dessas mulheres não são respeitados, as instituições não são preparadas para acolher esses filhos do cárcere e salvo alguns casos, algumas estão realmente recebendo o benefício da prisão domiciliar.

Palavras-chaves: Sistema Carcerário Brasileiro. Grávidas no Cárcere. Maternidade no Cárcere. 


\section{Sumário}

INTRODUÇÃO

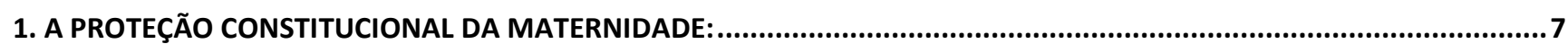

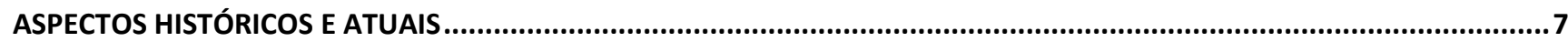

1.1 HISTORICIDADE SOBRE A PROTEÇÃO CONSTITUCIONAL DA MATERNIDADE ......................................................

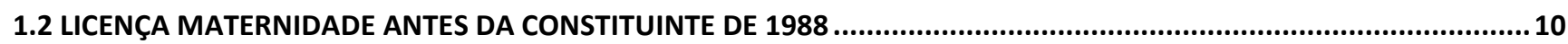

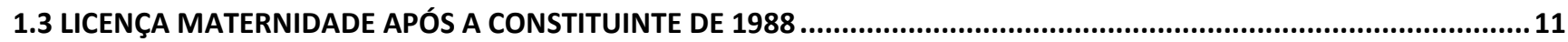

1.4 PROTEÇÃO CONSTITUCIONAL À MATERNIDADE NA ATUALIDADE .......................................................................13

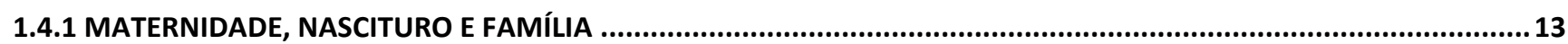

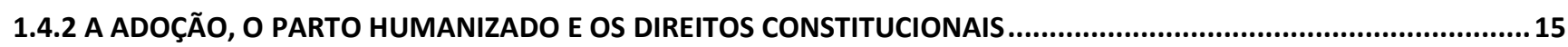

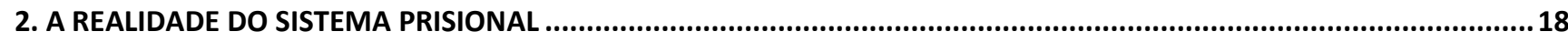

2.1 UM BREVE HISTÓRICO DA LEGISLAÇÃO PENAL........................................................................................... 18

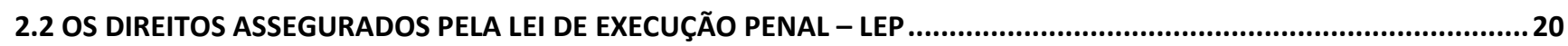

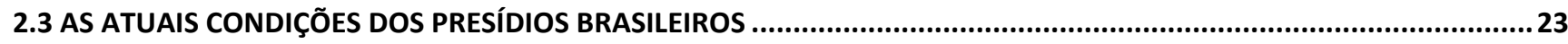

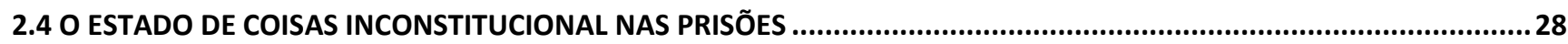

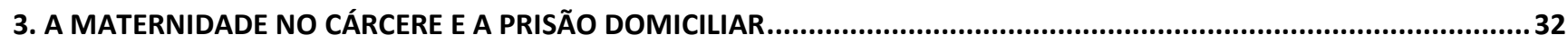

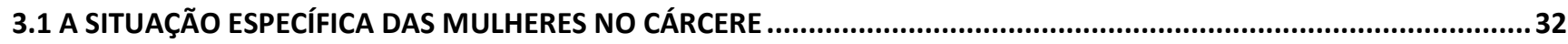

3.1.1 UM BREVE HISTÓRICO SOBRE O SURGIMENTO DOS PRESÍDIOS FEMININOS ....................................................32

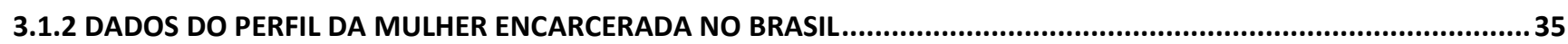

3.1.3 ESTUDOS SOBRE OS DIREITOS DAS ENCARCERADAS NO BRASIL ...............................................................40

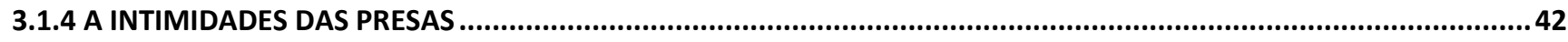

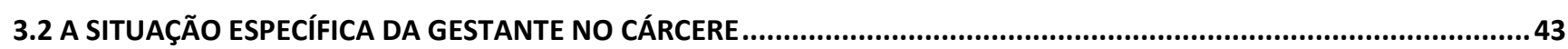

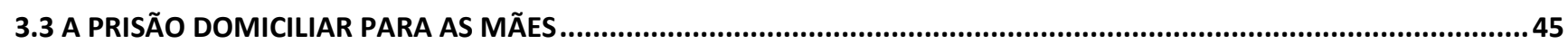

3.3.1 LEIS, DECRETOS E DIREITOS DAS GESTANTES E MÃES NO CÁRCERE.......................................................46

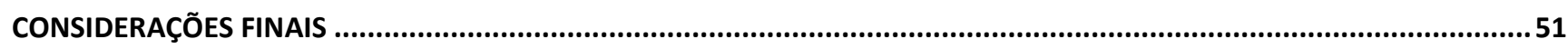

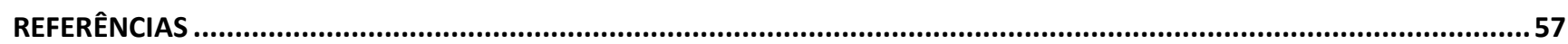




\section{INTRODUÇÃO}

O presente trabalho vem questionar sobre as condições das mulheres grávidas e mães encarceradas nas prisões do Brasil, seus direitos e a real atuação do Estado no Sistema Carcerário. Com as alterações causadas pela Constituição Federal de 1934 e, posteriormente, pela constituinte de 1988, os direitos das mulheres, principalmente em se tratando de maternidade, tiveram mudanças consideráveis. $\mathrm{E}$ serão tratadas neste artigo.

Baseando-se nesta confirmação, este trabalho tem como tema as mulheres no cárcere a gravidez, a maternidade e os direitos a prisão domiciliar. E como problema a seguinte questão: quais são os direitos das gestantes e mães encarceradas no sistema jurídico brasileiro?

Diante de tantas mudanças, pode-se ponderar que na atualidade, há grande controvérsia acerca da interpretação de "direitos" que são considerados pelo sistema carcerário e que passam longe das condições as gestantes e mães que vivem nos presídios femininos no Brasil.

Fundamentando-se na seriedade do estudo, sobre a hipótese, muitos autores discorrem sobre os direitos das detentas grávidas e mães nos presídios e afirmam que há muito a esclarecer sobre esses direitos e que muitas vezes são negados as detentas.

Nesta direção, o presente trabalho investigatório teve como objetivo geral elucidar as condições da maternidade nas penitenciárias. Além disso, foram estabelecidos como objetivos específicos: apresentar aspectos históricos da proteção constitucional da maternidade e também na atualidade; relatar sobre a realidade do sistema prisional; descrever sobre a gravidez e maternidade no cárcere e a prisão domiciliar.

Na metodologia trata-se de uma monografia de reflexão baseada em revisão narrativa de literatura, o tipo de estudo será efetivado a partir de pesquisa bibliográfica, sendo, desta forma, um estudo de pesquisa teórica.

Sob tal aspecto, a metodologia que será utilizada nesse estudo pode ser descrita como do tipo dedutivo, visto que, o método dedutivo parte das teorias e leis consideradas gerais e universais buscando explicar a ocorrência de fenômenos particulares. O exercício metódico da dedução parte de enunciados gerais (leis universais) que supostos constituem as premissas do pensamento racional e deduzidas chegam a conclusões. 
Sobre a amostragem, o presente estudo utilizará dados de artigos científicos existentes na base de dados online, Scielo, além de dissertações, revistas dos tribunais, livros e teses disponíveis em bancos de dados de universidades brasileiras.

Para efetivação deste estudo, utilizará artigos científicos referentes à temática abordada, não sendo delimitado um período, apenas prezando o uso das palavras chaves. O período compreendido para o levantamento bibliográfico compreendeu os meses entre janeiro de 2019 a novembro de 2019.

No que tange aos instrumentos de coleta de dados deste estudo serão utilizados os descritores: Sistema Carcerário Brasileiro, grávidas no cárcere e maternidade no cárcere. Sendo todo o material encontrado organizado e logo após apresentado em forma de análise, interpretação e reflexão dos dados coletados.

No que tange ao critério de inclusão estabelecido serão considerados os artigos científicos que respondem aos objetivos, problemática, confirmem ou refutem a hipótese levantada, que tenham sido publicados por autores brasileiros. Quanto ao critério de exclusão, segue para aqueles que não se atém ao critério de inclusão adotado.

Ressalta-se que em relação à coleta de dados dentro da pesquisa bibliográfica, a mesma será feita mediante o envolvimento das etapas escolha do tema; levantamento bibliográfico preliminar; formulação do problema; elaboração do plano provisório; busca das fontes; leitura do material; fichamento; organização lógica do assunto e redação do texto. E com esta metodologia acima citada será realizado os procedimentos de coleta de dados.

De acordo com a relevância social, este estudo justifica-se, uma vez que, empregando as ferramentas adequadas para a intervenção dos direitos das mulheres no cárcere principalmente as grávidas e mães, o profissional de direito tem em mãos a responsabilidade de apresentar a sociedade novos julgamentos sobre o assunto.

Nesta perspectiva, como relevância pessoal, foi ter motivada por estudos e pesquisas voltados para a importância do assunto. A motivação se refere ao desejo de compreender sobre a temática apresentada, sendo um fator de preocupação não só pessoal, mas também profissional. Acrescentase que os conhecimentos obtidos poderão fornecer um ganho de experiência, conhecimento e sustentação para meu futuro.

Ressalta-se que cientificamente este trabalho acrescentará aos estudiosos informações necessárias e aos profissionais de direito um entendimento sobre os recursos e as análises dos direitos das gestantes 
e mães encarceradas e também da prisão domiciliar. E também com o desenvolvimento em pesquisas neste campo, promoverá a compreensão dos indivíduos, gerando questionamentos, buscando alternativas e contribuirá para o próprio crescimento do direito incitando assim o seguimento das investigações.

O presente trabalho está organizado em três momentos. O primeiro capítulo discorre sobre os aspectos históricos e atuais sobre a proteção constitucional da maternidade; a licença maternidade antes e após a constituinte de 1988; e por último, a proteção constitucional à maternidade na atualidade.

No segundo capítulo dispõe sobre a realidade do Sistema Prisional Brasileiro. Será abordado sobre os direitos assegurados pela Lei de Execução Penal; foram mostradas as atuais condições dos presídios femininos o Brasil e logo em seguida discutiu o Estado de coisas inconstitucionais nas prisões.

O terceiro capítulo compõe sobre a maternidade no cárcere e a prisão domiciliar. Foram apresentadas as situações das mulheres no cárcere, as condições das gestantes e os direitos e deveres da prisão domiciliar para essas mães; e finalizando com as considerações finais e as referências utilizadas neste estudo.

\section{A PROTEÇÃO CONSTITUCIONAL DA MATERNIDADE:}

\section{ASPECTOS HISTÓRICOS E ATUAIS}

Neste capítulo será abordada a historicidade sobre a proteção constitucional da maternidade; a licença maternidade antes e após a constituinte de 1988; e por último, a proteção constitucional à maternidade na atualidade.

\subsection{HISTORICIDADE SOBRE A PROTEÇÃO CONSTITUCIONAL DA MATERNIDADE}

Cardone (2011) explica que a situação da mulher em princípios de 1824 era a mesma do Brasil-colônia: a mulher constituía mero enfeite do salão quando não se confinava entre as quatro paredes de seu lar para cuidar do marido ou dos filhos, ou então exercia funções de empregada doméstica ou escrava. A Constituição de 23 de março de 1824 e seu Ato Adicional de 12 de agosto de 1834 percebe no n. 2 que o movimento feminista se iniciou na Europa no século XIX e que pálidos reflexos tiveram no Brasil nesse mesmo século. 
Em passos lentos, em 1932, em plena vigência da Constituição de 1891, o Código Eleitoral, aprovado pelo decreto n. 21.076, de 24 de fevereiro, concedeu o direito de voto às mulheres. Dessa forma, foram abertas para as mulheres as possibilidades legais de atingirem cargos como o de deputado federal, ministro de Estado e Presidente da República, visto como uma das condições exigidas pela Constituição para se alçar tais postos era estar alistado como eleitor. (CARDONE, 2011).

E chega a constituição de 1934 e os direitos a maternidade nesta constituição é uma preocupação constante com a proteção à maternidade.

Para Martinez e Nóvoa (2019) para que tudo de melhor ocorra com a maternidade, é indispensável que os cuidados sejam oferecidos em todos os mais significativos momentos da vida da mulher, entre os quais se incluem os instantes fruídos no seio da família, no âmbito do trabalho e na relação com a sociedade.

Assim, eles continuam afirmando, cônscio de que os indivíduos passam 1/3 (um terço) de suas vidas em ambientes laborais ou em espaços sociais conexos, o legislador brasileiro consagrou a "proteção à maternidade" como um direito social no art. 6ㅇ da CF ao preceituar:

São direitos sociais a educação, a saúde, a alimentação, o trabalho, a moradia, o transporte, o lazer, a segurança, a previdência social, a proteção à maternidade e à infância, a assistência aos desamparados, na forma desta Constituição.

Em se tratando da condição de existência e de coexistência dos grupos humanos, conforme expressa Andrade (1996 apud MARTINEZ; NÓVOA, 2019) em parecer junto ao Ministério da Previdência e Assistência Social, em hipótese semelhante: "existe um núcleo de normas", fundamentais, essenciais, inerentes ao próprio ser humano, que o acompanham desde a concepção até a morte, que decorrem da própria natureza humana e que só mudarão quando mudar a natureza humana (...) às vezes chamados de 'direitos humanos'.

Neste sentido, Garcia (2012) afirma que:

(...) A maternidade é um valor elevadíssimo por si mesma, que transcende até a própria mãe, este direito é tanto mais elevado quanto mais intimamente está ligado ao direito à vida. A maternidade, além disso, tem uma relação com outro direito não menos relevante que é o da dignidade da família e dos laços familiares que devem ser cultivados e preservados, mormente entre mãe e filho. A estes direitos o Estado tem, não só de os reconhecer, como a obrigação de os servir, sob pena de o mesmo Estado perder a razão de ser da sua própria existência. 
Martinez e Nóvoa (2019) afirmam que a proteção à maternidade sempre foi preocupação não apenas das estruturas nacionais, mas também dos órgãos de atuação transnacional, entre os quais se destaca, obviamente, Organização Internacional do Trabalho, (OIT). Desde o seu primeiro ano de constituição, em 1919, a referida organização cuidou de oferecer balizas mínimas de Proteção à Maternidade.

Os autores continuam afirmando que na Conferência Geral da Organização Internacional do Trabalho da Liga das Nações, convocada na cidade de Washington pelo Governo dos Estados Unidos da América, aos 29 de outubro de 1919, depois de haver decidido adotar diversas propostas relativas ao emprego das mulheres antes ou depois do parto (inclusive a questão da indenização de maternidade), e também depois de haver decidido fossem essas propostas redigidas sob a forma de um projeto de convenção internacional, resolveu publicar a Convenção 3 e entendeu por bem submetê-la à ratificação dos seus membros.

Cardone (2011) esclarece que na Constituição de 1934, elaborada após 1919, ocasião da fundação da OIT e da realização da I Conferência Internacional do Trabalho, em que se redigiu a Convenção n. 3, relativa ao emprego de mulheres antes e depois do parto, adotou vários dispositivos com relação aos direitos trabalhistas das mulheres.

Garcia (2012) reforça que, desde a Constituição de 1934, no art. 121, h (assistência médica e sanitária ao trabalhador e à gestante, assegurando a esta descanso antes e depois do parto, sem prejuízo do salário e do emprego), e § 3.o (os serviços de amparo à maternidade e à infância) e no art. 138: Incumbe à União, aos Estados e aos Municípios, nos termos das leis respectivas: (...) c) amparar a maternidade e a infância, encontra-se a preocupação com tais situações, da maior importância para o País.

Oliveira (2016) afirma o tema sempre teve vinculação com o direito do trabalho, de tal modo que a primeira norma brasileira, que se tem notícia, acerca da proteção à maternidade, encontra-se na Lei 1.596, de 29 de dezembro de 1917, do Estado de São Paulo, a qual dispunha em seu art. 95, verbis: "As mulheres, durante o último mês de gravidez e o primeiro do puerpério, não poderão trabalhar em quaesquer estabelecimentos industriaes".

Em seguida, o autor reafirma que o tema se desenvolveu especialmente mediante as Convenções 3 e 4 da OIT, ambas de 1919 e ratificadas pelo Brasil em 1934, sempre normativamente adstrito ao direito obreiro. 
Hoje, contudo, é possível verificar, nas disposições constitucionais sobre esse direito, a sua complexidade de possuir cunhos trabalhista (art. 7.․, XVIII), previdenciário (art. 201, II) e assistencial (art. 203, I) ao mesmo tempo. (OLIVEIRA, 2016).

\subsection{LICENÇA MATERNIDADE ANTES DA CONSTITUINTE DE 1988}

A literatura explana que na constituição 1937, a Carta Magna outorgada após o golpe de Estado de 1937 seguiu a trilha traçada pela de 1934, mantendo mais ou menos os mesmos direitos à mulher, expressando-se, porém, de maneira diversa.

Neste sentido Cardone (2011) salienta:

Foi conservada a possibilidade da mulher galgar postos políticos (arts. 51, $81 \mathrm{e}$ 88), como os de representantes de Estado no Conselho Federal, Presidente da República e Ministro de Estado; o direito ao voto igualmente foi mantido (art. 117); o princípio de isonomia e a faculdade de acesso a cargos públicos (art. 122 , ns. 1 e 3) permaneceram igualmente; os mesmos direitos trabalhistas (art. 137, "k") foram concedidos, com exceção do direito de ter assegurado o emprego, por ocasião do descanso remunerado pré e pós parto. Com efeito, o art. 137 e sua letra "1" dispuseram: "A legislação do trabalho observará, além de outros, os seguintes preceitos: ... 1) assistência médica e higiênica ao trabalhador e à gestante, assegurado a esta, sem prejuízo do salário, um período de repouso antes e depois do parto", enquanto a letra "h", do art. 121, da Constituição de 1934, dispusera: "assistência médica e sanitária ao trabalhador e à gestante, assegurado a esta descanso antes e depois do parto, sem prejuízo do salário e do emprêgo..."

Garcia (2012) destaca que na Constituição de 1937, o art. 127 especifica: "a infância e a juventude devem ser objeto de cuidados e garantias especiais por parte do Estado, que tomará as medidas destinadas a assegurar-lhes condições físicas e morais de vida sã e de harmonioso desenvolvimento das faculdades".

Outra declaração de Garcia (2012) é o art. 157, X, da Constituição de 1946 que estabelece o "direito da gestante a descanso antes e depois do parto, sem prejuízo do emprego nem do salário"; "XVI previdência, mediante contribuição da União, do empregador e do empregado, em favor da maternidade (...)".

E Garcia (2012) finaliza afirmando que também a Constituição de 1967, no art. 158, XI, estabelecia "descanso remunerado da gestante, antes e depois do parto, sem prejuízo do emprego e do salário"; da mesma forma, o art. 165, XI, da EC 1/1969. (GARCIA, 2012).

A autora Cardone (2011) discorda dizendo que tal dispositivo não é autoaplicável. Seria necessária uma lei que dissesse a que espaço de tempo deveria corresponder o período de descanso. Esta lei já 
existia antes da Constituição de 1946 e foi mantida posteriormente. Trata-se do decreto-lei n. 5.452, de 1o de maio de 1943, que aprovou a Consolidação das Leis do Trabalho e dispõe no seu art. 392: "É proibido o trabalho da mulher grávida no período de seis semanas antes e seis semanas depois do parto". Na prática vemos os empregadores despedindo suas empregadas tão logo tomam conhecimento de sua gravidez.

Os autores Penteado, Margraf; Razaboni Junior (2018) elucidam que muito embora exista um caráter protecionista, há doutrinadores que defendem que a proteção diferenciada levou a uma espécie de discriminação na contratação da mulher, uma vez que os empregadores enxergavam como verdadeiro ônus as garantias da mulher.

Eles continuam afirmando que, os empregadores preferiam, então, contratar homens, que não tinham tais garantias legais, ou ainda impunham requisitos discriminatórios para admissão de mulheres, como as solteiras, com exigência de exame de urina, com a finalidade de saber, no momento da contratação, se a mulher se encontrava em estado gravídico. Todos esses abusos terminaram por concebera Lei 9.029/1995 que proíbe a exigência de atestados de gravidez ou esterilização para que se efetive a admissão ou durante o curso do contrato de trabalho.

\subsection{LICENÇA MATERNIDADE APÓS A CONSTITUINTE DE 1988}

Os autores Penteado, Margraf; Razaboni Junior (2018) exemplificam que dentre tantos avanços na luta por direitos, talvez o mais significativo foi o reconhecimento, pela Constituição da República de 1988, da igualdade de direitos e obrigações entre homens e mulheres, o que traduz a abominação do Estado a qualquer tipo de discriminação.

Os autores citados continuam afirmando que a proteção da mulher pela legislação é necessária devido ao fato de que ela sempre foi vista como um ser frágil, dependente e inferior física e intelectualmente, e recebendo, comprovadamente, menores salários que os homens, e a necessidade de proteção só evidenciam a existência, de fato, de discriminação.

Todavia, embora essa garantia seja de fundamental importância, existem casos em que, por particularidades impostas pelo próprio gênero - homem/mulher - necessitam de tratamento diferenciado. É o caso das gestantes. (PENTEADO; MARGRAF; RAZABONI JUNIOR, 2018).

Garcia (2012) explica que na Constituição de 1988, o art. 7.ํ, XVIII, assegura: "licença à gestante, sem prejuízo do emprego e do salário, com a duração de cento e vinte dias". E, na legislação ordinária, a Lei 8.213/1991, dispondo sobre os Planos de Benefícios da Previdência Social refere, no art. 71, o 
correspondente salário-maternidade, "observadas as situações e condições previstas na legislação no que concerne à proteção à maternidade".

Para bem entender-se o tema em discussão, há necessidade de uma incursão sobre o instituto do "salário-maternidade". Neste sentido Oliveira e Lopes (2000) elucidam que:

\begin{abstract}
"O salário do período destinado à licença-maternidade antes era encargo do empregador. Nesse sentido dispunha o parágrafo único do art. 393, modificado pelo Dec. 229, de 28.02.1967. O benefício passou a ser ônus da Previdência, custeado pelas contribuições patronais com base sobre a folha de pagamento. Vale dizer que o empregador efetua à gestante o pagamento dos salários devidos no período e se ressarce, posteriormente, através de descontos nos recolhimentos que terá que fazer à Previdência".
\end{abstract}

Licença-maternidade é a designação da prestação previdenciária prevista na doutrina estrangeira da seguridade social, conforme refere Jean-Jacques Dupeyrux: "I'assurance maternité", segurançamaternidade, durante o período de repouso precedente e após o parto. (GARCIA, 2012).

Seguro revestido de certa originalidade, diz o autor, "que, ademais, não tem por objetivo apenas garantir auxílio material; ele se inscreve no conjunto das medidas centradas na proteção da mãe e da criança". (GARCIA, 2012).

Os autores Penteado, Margraf; Razaboni Junior (2018) reafirmam que por essas razões é tão importante a conduta protecionista do Estado, não no sentido de privilegiar o gênero feminino, mas sim de garantir o direito das mulheres trabalhadoras.

Nesse sentido, em 1995 houve a edição da Lei 9.029, que proíbe e criminaliza qualquer prática discriminatória para contratação ou manutenção da relação de trabalho de uma mulher, tendo como fundamento o aspecto fisiológico.

Afirmando essa posição os autores Penteado, Margraf; Razaboni Junior (2018) afirma:

\begin{abstract}
"a mulher não é dotada da mesma resistência física que o homem e a sua constituição é mais frágil, de modo a exigir do direito uma atitude diferente e mais compatível com o seu estado", e, por outro lado, o fundamento social, no qual "interessa à sociedade a defesa da família, daí por que o trabalho da mulher deve ser especialmente protegido, de tal modo que a maternidade e as solicitações dela decorrentes sejam devidamente conciliadas com as ocupações profissionais".
\end{abstract}

Em 1999, o Capítulo III do Título III da CLT foi ampliado pela Lei 9.799, que inseriu novos artigos, igualando as garantias à vaga de emprego para mulheres, principalmente no que se refere a exigências relacionadas a sexo, idade, cor ou estado civil. (PENTEADO; MARGRAF; RAZABONI JUNIOR, 2018). 


\title{
1.4 PROTEÇÃO CONSTITUCIONAL À MATERNIDADE NA ATUALIDADE
}

Um questionamento feito recentemente por Martinez e Nóvoa (2019) sobre o porquê da proteção a maternidade cogita a seguinte reflexão que, a maternidade é a mais significativa forma de assegurar a preservação da própria espécie e está sendo negligenciada. Eles elucidam:

\begin{abstract}
A despeito de sua inegável importância teórica e prática, o direito fundamental à proteção à maternidade não tem merecido a devida atenção dos constitucionalistas brasileiros. Quando não completamente negligenciado nos estudos sobre direitos fundamentais, ele recebe, no mais das vezes, um tratamento incidental e extremamente superficial. Tal ocorre por manifesto esquecimento de que a "maternidade" é a protagonista da perenização do povo de um lugar. $O$ oferecimento de proteção à mulher gestante, portanto, antes de ser ato de amparo ao gênero feminino, é a mais significativa forma de assegurar a preservação da própria espécie.
\end{abstract}

Ao longo dos séculos, as mulheres foram conquistando, a duras penas, alguns direitos e proteções na esfera laboral, sendo que as principais se referem à licença-maternidade, pausa para amamentação e a estabilidade.

De acordo com Penteado, Margraf e Razaboni Junior (2018) no Fórum Econômico Mundial foram apresentadas conclusões de pesquisas do Relatório de Desigualdade Global de Gênero 2016, e, em tais pesquisas, apontou-se que, entre 144 países, o Brasil ocupa o 129o lugar, sendo ultrapassado, inclusive, por países criticados por violações aos direitos das mulheres, como Irã, lêmen e Arábia Saudita, [que] estão em melhor posição que o Brasil.

Nesse particular, ressalta Martinez e Nóvoa (2019) cabe a lembrança da existência de um princípio de "proibição de défice", que obriga o Estado a assegurar um nível mínimo e adequado de proteção aos direitos fundamentais e a assumir a responsabilidade pelas omissões legislativas que não assegurem o cumprimento dessa imposição genérica. A insuficiente realização dos deveres de proteção do Estado em favor da maternidade, aliás, além de caracterizar violações ao referido princípio de proteção, constitui flagrante ato antijurídico.

\subsubsection{MATERNIDADE, NASCITURO E FAMÍLIA}

Nunca será demasiada a lembrança de que a maternidade produz uma série de modificações na mulher, fazendo com que ela solicite e espere atitudes de amparo de todos os que circundam a sua vida familiar, social e profissional.

Martinez e Nóvoa (2019) lembram que muitos cuidados não praticados no cotidiano das mulheres passam a ser exigíveis desde os primeiros instantes do período gestacional, passando pelos 
indispensáveis exames pré-natais, pela chegada e a recepção do bebê e seu acompanhamento durante toda a infância. A proteção à maternidade e à infância alçou, por isso, a qualidade de direito social. Reitere-se que a lei protege o instituto "maternidade", e não unicamente a gestante, o nascituro ou o recém-nascido, entendendo-o como um complexo que envolve um conjunto de estados temporários, todos merecedores de diferenciada atenção.

Silva (2009 apud PENTEADO; MARGRAF; RAZABONI JUNIOR, 2018) relatam que, sobre a proteção à maternidade, é preciso olhar este tema, entretanto, não só pelo viés da proteção à trabalhadora, mas também ao nascituro. Que o tema proteção à maternidade deve ter duplo alcance, sendo um por prestigiar efetivamente a gestante, para que ela não vivencie maiores sobressaltos na gravidez, de consequências imprevisíveis e irremediáveis, e o outro alcance deve ser em relação ao nascituro, com a finalidade de que ele tanto "possa se desenvolver em condições mais favoráveis como, sobretudo, venha ao mundo em condições ao menos medianas de nutrição e higiene".

O art. 201, II, do texto constitucional é claríssimo nesse sentido. Martinez e Nóvoa (2019) explicam que o artigo dispõe que a Previdência Social oferecerá "proteção à maternidade, especialmente à gestante". A gestante neste contexto é, sem dúvidas, a protagonista do espetáculo que envolve a reprodução humana, mas a proteção não se destina unicamente a ela, embora, obviamente, se destine especialmente a ela. O amparo à maternidade, portanto, envolve múltiplas fases, desde o período gestacional até os acontecimentos pós-parto, inclusive o período de amamentação e de cuidados com o infante.

Nascimento e Villa Boas (2016) afirmam que a Lei no 11.770/2009 instituiu o Programa Empresa Cidadã - a Administração Pública, direta, indireta e fundacional são autorizadas por esta lei a instituir programa que garanta prorrogação da licença-maternidade para suas servidoras -, ampliando o período de licença-maternidade para cento e oitenta dias para as empresas.

Os autores continuam dizendo que a adesão das empresas ao Programa é facultativa, e tal ampliação somente ocorrerá se a licença for pedida pela gestante, até o primeiro mês após o parto, o que revela duas condições fundamentais para a prorrogação da licença-maternidade: a) condição objetiva que exige ser a empresa participante do programa "Empresa Cidadã"; b) condição subjetiva que exige que a mulher requeira a ampliação da licença até o primeiro mês após o parto.

Sobre a morte do filho, Martinez e Nóvoa (2019) reforça que as normas jurídicas infraconstitucionais têm seguido uma lógica. Exemplo disso é visível na situação em que se oferece licença-maternidade e 
salário-maternidade em favor da gestante que, por um pesado infortúnio, perde o filho no momento do parto e, em consequência disso, expede-se a certidão de óbito.

Martinez e Nóvoa (2019) elucida que o sistema jurídico entende que qualquer evento ocorrido depois da 23ạ semana de gestação é entendido como parto e que, sendo parto, é irrelevante que dele provenha um natimorto. Se isso ocorre, em atenção às expectativas de todos os familiares, concedese à gestante exatamente o mesmo tempo que ela teria fruído se o seu tão esperado filho estivesse vivo e no seio da família. Cita-se, nesse particular, o conteúdo do art. 343 da Instrução Normativa $77 / 2015$ do INSS.

Martinez e Nóvoa (2019) relata também que é visível a proteção jurídica da família nas situações em que a morte não é da criança, mas sim da gestante. Nesses casos, também levando em conta a sensibilidade de que a proteção se dá à maternidade, e não à mãe, o art. 392-B da CLT, posiciona-se no sentido de que "em caso de morte da genitora, é assegurado ao cônjuge ou companheiro empregado o gozo de licença por todo o período da licença-maternidade ou pelo tempo restante a que teria direito a mãe, exceto no caso de falecimento do filho ou de seu abandono".

Martinez e Nóvoa (2019) Outra variável que sinaliza sobre a proteção de todo o núcleo familiar, e não apenas da mãe é também visível no caso de seu falecimento. A Lei Complementar 146, de 25 de Junho de 2014 expandiu a estabilidade provisória dada à genitora a quem detiver a guarda de seu filho, até o limite de cinco meses após o parto, em caso de falecimento desta.

Martinez e Nóvoa (2019) esclarece que na situação acima citada, é válido registrar que se a guarda não tiver sido obtida judicialmente, ela será aplicada àquela pessoa que, na estruturar familiar, ficar responsável pelos cuidados da criança, a exemplo do pai que assume naturalmente a guarda do filho na falta da mãe. Na falta de ambos, a guarda ora analisada deverá ser concedida obrigatoriamente pelo juiz a outro membro da família ou a quem tenha capacidade de incumbir-se dessa nobre e importante missão.

\subsubsection{A ADOÇÃO, O PARTO HUMANIZADO E OS DIREITOS CONSTITUCIONAIS}

Contudo, em se tratando de maternidade, alguns detalhes sobre as decisões dos direitos das mães adotivas e do parto humanizado geram polêmicas.

Martinez e Nóvoa (2019) relatam que o princípio da afetividade igualou filhos biológicos e adotivos. Apesar de a palavra "afeto" não estar no texto constitucional, esse é, sem dúvida, o princípio norteador do direito das famílias. Segundo eles: 
Por não estar no texto constitucional, este praticamente olvidou as proteções que poderiam ser oferecidas à maternidade ou paternidade afetiva. Toda situação em que se tratava de proteção à maternidade no âmbito constitucional era visível apenas em relação à variável biológica, sendo prova disso o texto dos artigos que oferecem licença-maternidade à gestante (art. 70, XVIII) e estabilidade à mulher grávida, desde a concepção até cinco meses após o parto. Nada, absolutamente nada, se dizia sobre a maternidade/paternidade afetiva, como se - por equívoco interpretativo - ela não produzisse os mesmos efeitos e proteções.

Para Garcia (2012) a jurisprudência brasileira, salvo algumas expressivas decisões, veio a excluir a mãe adotiva do direito a licença maternidade. No conhecido RE 197.807/RS, sendo recorrente o Estado do Rio Grande do Sul e relator o Min. Octavio Gallotti, em decisão de 30.05.2000, decidiu o STF, por votação unanime: “Não se estende à mãe adotiva o direito à licença, instituído em favor da empregada gestante pelo inc. XVIII do art. 7.o da CF/1988, ficando sujeito ao legislador ordinário o tratamento da matéria".

Ela delibera:

Ao argumento principal do Tribunal a quo (TRT - 4. a Reg., rel. Min. Beatriz Brun Goldschmidt): "um dos objetivos desta norma constitucional é direcionado a atender o recém-nascido", que "o direito é uma realidade dinâmica em perpétuo movimento, acompanhando as relações humanas (...) as experiências históricas, sociológicas, axiológicas, que se complementam", houve por bem acolher a Suprema Corte o recurso oposto, básico em que "a ratio da licençagestante está na necessidade biológica do resguardo pós-parto", aquiescendo em "não haver impedimento à concessão de semelhante beneficio à mãe adotante, mediante lei ordinária, legitimada mesmo pelos princípios inscritos na Constituição da República (...)".

Garcia (2012) explica que em decisão polêmica, o juiz federal de Pelotas (RS), Cristiano Basser S. Diniz ressalta que "o tratamento igualitário para a mãe adotiva e a biológica se justifica pela necessidade de assegurar-se a convivência entre mãe e filho nos primeiros meses devida, independente da natureza do vinculo. Esse relacionamento é tão ou mais necessário na adoção quanto na relação biológica, porque se está iniciando a relação afetiva entre mãe e filho. E ainda, porque a criança sofre um défict afetivo causado pela separação da mãe biológica".

Nascimento e Villa Boas (2019) acrescentam que conforme disposto no artigo 392-A da CLT, acrescentado pela Lei $n=10.421 / 2002$, todas as mães adotivas e as mulheres que recebem crianças de até oito anos de idade para guarda judicial, passam a ter o direito à licença-maternidade de cento e vinte dias, sem o prejuízo do emprego e do salário, recebendo o pagamento do benefício previdenciário (salário maternidade) da Previdência Social, conforme regras fixadas pela Lei no $8.213 / 1991$. 
Martinez e Nóvoa (2019) concordam e reafirmam, que somente por meio da Lei 10.421 de 15 de abril de 2002, fundada na ideia de progressividade social, é que se estendeu à mãe adotiva (somente à "mãe", inicialmente) o direito à licença-maternidade e ao salário-maternidade. A mudança, portanto, foi operada tanto no âmbito da relação jurídica de direito material quanto na esfera da relação jurídica previdenciária. E para os homens adotantes? Os autores afirmam que a Resolução 20/2009 do CSJT -Conselho Superior da Justiça do Trabalho - foi o primeiro texto normativo a dar tratamento isonômico a mulheres e homens adotantes:

Cabe sobressaltar a importância da Resolução 20/2009 do CSJT- Conselho Superior da Justiça do Trabalho. Ao perceber que a adoção é um ato de amor que pode ser praticado indistintamente no universo feminino ou masculino e que não existia motivação razoável para conceder a "licença por adoção" unicamente em favor das mulheres, o referido órgão de supervisão administrativa, orçamentária, financeira e patrimonial da Justiça do Trabalho, rompendo com a literalidade das normas infraconstitucionais e oferecendo um exemplo de cidadania e inclusão, deu caráter normativo à decisão em que acolhera a pretensão de licença em favor de servidor do judiciário trabalhista, solteiro, que adotou uma criança.

Foi rompido um paradigma, Martinez e Nóvoa (2019) esclarecem que a partir do ato histórico do CSJT, abriram-se as portas para o oferecimento de licença-maternidade e salário-maternidade, indistintamente para homens ou mulheres adotantes. Alguns anos depois, o Congresso Nacional universalizou o entendimento mediante a Lei 12.873, de 24 de outubro de 2013.

Os autores citados reforçam que a norma citada rompeu mais um "tabu jurídico" e incluiu no art. 392C da CLT e no art. 71-B da Lei 8.213/91 previsão no sentido de que o homem (empregado/segurado) também poderá fruir licença-maternidade e receber salário-maternidade quando adotar ou obtiver guarda judicial para fins de adoção.

Consolidou-se, enfim, a integral proteção à maternidade com uma visão holística, que protege não apenas um dos integrantes da família - a mãe ou o filho - mas todos aqueles que nela estão integrados.

Sobre o parto humanizado, mais um direito a maternidade, Oliveira (2016) relata que, em decorrência dessa função social, de status constitucional, a Lei 11.108, de 7 de abril de 2005, estipulou norma que reflete o direito à humanização do parto, ao incluir na Lei 8.080, de 19 de setembro de 1990, garantia às parturientes do direito à presença de acompanhante durante o trabalho de parto, parto e pós-parto imediato, no âmbito do Sistema Único de Saúde - SUS. 
Intenta-se demonstrar, nesse passo, que a proteção constitucional à maternidade, direito fundamental social, traz em seu âmago o direito ao parto humanizado, tão infelizmente relegado nesse momento histórico. Deve ser observado que referido direito inclui a necessária atenção integral e humanizada ao recém-nascido. Destaque-se a Portaria 371, de 7 de maio de 2014, do Ministério da Saúde, cujo art. 4. dispõe especificamente sobre o procedimento humanizado no imediato momento do nascimento com vida. São medidas importantes e que promovem o mais lídimo respeito à vida, em seu momento mais sublime. (OLIVEIRA, 2016).

Martinez e Nóvoa (2019) finalizam afirmando que é dever do Estado a proteção. Eles afirmam que o dever geral de efetivação está associado ao monopólio estatal do exercício da força. Com isso, desejase dizer que, diante da vedação à autotutela, não se pode esperar a concretização compulsória da proteção à maternidade por qualquer outro sujeito que não seja o próprio Estado. Ele - em qualquer um dos seus poderes - está juridicamente vinculado à materialização dos deveres de proteção. Cabe a ele a proteção a maternidade.

Nesse sentido, muitos estudos mostram que um dos principais fatores que favorece a discriminação da mulher no trabalho é a condição da mulher em relação à maternidade, situação esta, que muito embora não direcione o ônus de pagar o período da licença gestante à empresa empregadora, faz com que se sinta indiretamente prejudicada pelo afastamento da trabalhadora, apesar de serem os custos do empregador relacionados à contratação das mulheres muito reduzidos, fato que não justifica as desigualdades entre homens e mulheres. (NASCIMENTO; VILLAS BÔAS, 2015).

\section{A REALIDADE DO SISTEMA PRISIONAL}

Neste capítulo será abordada a historicidade sobre a Legislação Penal; os direitos assegurados pela Lei de Execução Penal - LEP; as atuais condições dos presídios brasileiros e o Estado de coisas inconstitucional nas prisões.

\subsection{UM BREVE HISTÓRICO DA LEGISLAÇÃO PENAL}

Sobre a Legislação Penal, Angotti (2018) relata que a Constituição Imperial de 1824 e o Código Criminal de 1830 foram os primeiros instrumentos a refletir, no plano legal, o debate que vinha ocorrendo nos meios jurídicos e políticos sobre o encarceramento no país. Em seu artigo 179, incisos XIX, XX e XXI, a Constituição de 1824 ressaltava, respectivamente, que: 
"desde já ficam abolidos os açoites, a tortura, a marca de ferro quente, e todas as mais penas cruéis"; "nenhuma pena passará da pessoa do delinqüente (...)"; e "as Cadê as serão seguras, limpas, bem arejadas, havendo diversas casas para separação dos Réos, conforme suas circunstâncias, e natureza dos seus crimes".

Batista (2017) concorda e afirma que neste período, a vingança e a tortura eram mecanismos adotados no Brasil como maneira de punir o infrator, sendo muito utilizado também entre os indígenas.

Nas palavras da autora Ghisleni (2014):

Na Antiguidade, a pena privativa de liberdade não teve nenhum papel de destaque, uma vez que a prisão tinha por objetivo a simples contenção e guarda de réus, de tal forma que eles fossem preservados fisicamente até seu julgamento definitivo. Calabouços sombrios, castelos, torres e conventos abandonados são apenas alguns dos lugares empregados como prisão, o que exemplifica as condições subumanas às quais os réus se submetiam para aguardar a sua execução. Fica muito claro, todavia, o caráter de crueldade empregado nas penas da Antiguidade.

Entretanto, Angotti (2018) elucida que o Código Criminal de 1830, apesar de manter as penas de galés, a pena capital e castigos corporais, inovou ao introduzir, em seu artigo 46, a pena de prisão com trabalho diário, em prática nos países cujas técnicas penitenciárias eram consideradas de vanguarda.

A criação do Código Penal de 1940, que entrou em vigor em 1942, representa um importante momento para o Direito Penal nacional. É nesse cenário, portanto, que surgem o Código Penal e o Código de Processo Penal de 1940 e 1941, respectivamente.

Ghisleni (2014) explica que em 1942 o referido Código passou a vigorar em todo o país. O sistema de penas e medidas de segurança do código de 1940, contudo, não estava de acordo com a Constituição posta. Por isso a doutrina e a jurisprudência tomaram para si a função de atenuar o sistema, e, em 1969, portanto, foi sancionado o Código Penal de Nélson Hungria, que veio modificar o código anterior.

Num passado recente, em 1982, os anteprojetos da parte geral do Código Penal e da Lei de Execução Penal foram encaminhados à Presidência da República. Ambos foram aprovados pelo Congresso em 1984, sendo as leis 7.209 e 7.210, respectivamente.

Com relação à reforma na parte geral do código Ghisleni (2014) afirma que foi de fundamental importância, uma vez que ela pôde estar mais coerente em relação aos Direitos Humanos. A possibilidade de perpetuação da pena foi eliminada, sendo o máximo 30 anos. Além disso, também tornou possível o livramento condicional. 
Não podemos finalizar este item, entretanto, sem falar que atualmente, nosso ordenamento abrange as penas privativas de liberdade e as restritivas de direito. A pena de morte é vedada, salvo nos casos de guerra declarada. Conforme artigo abaixo da Constituição Federal de 1988:

Art. 5o Todos são iguais perante a lei, sem distinção de qualquer natureza, garantindo-se aos brasileiros e aos estrangeiros residentes no País a inviolabilidade do direito à vida, à liberdade, à igualdade, à segurança e à propriedade, nos termos seguintes: XLVII - não haverá penas: a) de morte, salvo em caso de guerra declarada, nos termos do art. 84, XIX; b) de caráter perpétuo; c) de trabalhos forçados; d) de banimento; e) cruéis. (CF, 1988).

E reforçando, no artigo citado, as penas perpétuas, de trabalhos forçados, de banimento e as cruéis, são expressamente vedadas pela nossa Constituição Federal.

\subsection{OS DIREITOS ASSEGURADOS PELA LEI DE EXECUÇÃO PENAL - LEP}

Ghisleni (2014) explica que a Lei no 7.210/84 - Lei de Execução Penal, conhecida como LEP -, tem por objetivo assegurar aos condenados garantias mínimas de seus direitos e amenizar significativamente as violações que possam resultar da situação supracitada. Além disso, de acordo com a lei, o apenado deve submeter-se ao conjunto de normas de execução da pena, de forma a cumprir com os deveres que lhe são designados perante o Estado.

A autora citada afirma que conforme o artigo 10 da LEP, a função da execução penal é fazer cumprir as disposições da sentença ou decisão criminal, ao passo que também deve proporcionar condições adequadas para que haja uma integração social harmônica do condenado e do internado. A LEP, portanto, é o meio coercitivo pelo qual se garante que a execução penal cumpra com essa função.

Mirabete e Fabbrini (2014) descrevem que no artigo 10 da lei traz a disposição no sentido de que o Estado tem o dever de dar assistência ao internado e ao condenado, de forma a prevenir o crime e orientar o retorno destes indivíduos à sociedade.

Na redação do artigo 38 da LEP consta que, além das obrigações legais inerentes ao seu estado, o apenado deve submeter-se às normas de execução da pena, estando suas obrigações, no que diz respeito à disciplina, situadas nos artigos 44 e seguintes da LEP.

Conforme Mirabete e Fabbrini (2014) estão previstos no artigo 39 da LEP um rol taxativo dos deveres do preso. São eles: 
Execução do trabalho, das tarefas e das ordens recebidas, submissão à sanção disciplinar imposta, indenização à vítima ou aos seus sucessores, indenização ao Estado, quando possível, das despesas realizadas com a sua manutenção, mediante desconto proporcional da remuneração do trabalho, higiene pessoal e asseio da cela ou alojamento e conservação dos objetos de uso pessoal, comportamento disciplinado e cumprimento fiel da sentença; obediência ao servidor e respeito a qualquer pessoa com quem deva relacionar-se; urbanidade e respeito no trato com os demais condenados; conduta oposta aos movimentos individuais ou coletivos de fuga ou de subversão à ordem ou à disciplina;

E logo a seguir no artigo 41 da LEP é responsável por elencar os direitos do preso e dentre eles conforme Mirabete e Fabbrini (2014) são os seguintes:

Contato com o mundo exterior por meio de correspondência escrita, da leitura e de outros meios de informação que não comprometam a moral e os bons costumes, visita do cônjuge, da companheira, e de parentes e amigos em dias determinados, alimentação suficiente e vestuário, atribuição de trabalho e sua remuneração, previdência social, constituição de pecúlio, proporcionalidade na distribuição do tempo para o trabalho, o descanso e a recreação, assistência material à saúde, jurídica, educacional, social e religiosa, igualdade de tratamento, salvo quanto às exigências da individualização da pena.

Batista (2017) elucida que é visível que a superlotação no sistema carcerário, acaba dificultando que o condenado possa usufruir desses direitos, pois a cada dia vem aumentando o número de presos dentro das celas, resultando num número negativo para a questão.

Ghisleni (2014) sobre os direitos humanos, considerando o que já foi redigido, percebe-se que não está compatível com a atual realidade do sistema carcerário brasileiro, não exatamente por conta de eventuais falhas em sua redação, mas por conta do descaso com o qual os apenados são tratados dentro da prisão. Os problemas são inúmeros e vão desde a violência física até a falta de alimentação.

De acordo com Mirabete e Fabbrini (2014) embora a finalidade das penas privativas de liberdade, quando aplicadas, tenham o objetivo e a esperança de alcançar a recuperação, a ressocialização, à readaptação, a reinserção ou reeducação social tenha penetrado formalmente nos sistemas normativos, questiona-se muito a intervenção estatal na esfera da consciência do presidiário, para se apurar se tem o Estado o direito de oprimir a liberdade interna do condenado, impondo-Ihe concepções de vida e estilos de comportamento.

De acordo com Batista (2017) o regime fechado, conforme disposto no artigo 34 do Código Penal, deve ser exercido em locais de segurança máxima ou média, obrigatoriamente, quando a pena for superior a oito anos, mesmo que o réu não seja reincidente. Os locais de máxima e média segurança são 
estabelecimentos fechados - penitenciárias, para onde são deslocados os presos considerados perigosos.

Ghisleni (2014) afirma que são três as espécies de penas privativas de liberdade: reclusão, detenção e prisão simples. A prisão simples aplica-se apenas às contravenções penais, o que quer dizer que ela não pode ser cumprida em regime fechado. Além disso, cumpre salientar que o contraventor condenado não pode ficar no mesmo estabelecimento reservado aos criminosos.

No que diz respeito aos regimes de reclusão e detenção, algumas diferenciações devem ser feitas. Segundo Ghisleni (2014, p. 194):

O regime de reclusão destina-se aos autores de delitos mais graves e abrange três modalidades de regime, podendo ser cumprido inicialmente em regime fechado, semiaberto ou aberto. Já o regime de detenção é aplicado aos delitos menos graves e, ao contrário da reclusão, abrange somente as modalidades de regime aberto e semiaberto. A reclusão pode gerar incapacidade para o exercício do poder familiar, da tutela e da curatela, conforme dispõe o inciso segundo do artigo 92 do Código Penal, o que não se verifica na detenção, posto que, neste caso, não há possibilidade de perda do poder familiar. À reclusão, aplica-se medida de segurança detentiva, ao passo que na detenção podemos falar em medida de segurança restritiva. Ademais, a fiança, no caso da reclusão, é arbitrada pela autoridade judicial, e, nos casos de detenção, ela pode ser concedida pela autoridade policial.

Batista (2017) discorre o seguinte, que a finalidade da pena é a defesa social pela proteção de bens jurídicos considerados essenciais à manutenção da convivência em sociedade, sendo este o fim do Direito Penal, e a pena, o instrumento de que ele se utiliza para atingi-lo, partindo do princípio de que as penas e medidas de segurança devem realizar a proteção dos bens jurídicos e a reincorporação do delinquente à comunidade.

Ghisleni (2014) explica que os artigos 87 a 90 da Lei de Execução Penal (LEP) dispõem que a execução da pena em regime fechado será em penitenciária, na qual o condenado fique isolado da sociedade. Os artigos 91 e 92 da LEP expõem que ao regime semiaberto ficam destinadas as colônias agrícolas ou industriais. Por fim, de acordo com os artigos 93 a 95 da LEP, no regime aberto o período diurno é destinado ao trabalho e, durante a noite, o apenado deve se recolher à casa de albergados.

De acordo com o artigo 112 da LEP, a pena será cumprida conforme o regime fixado na sentença. Por conta do sistema progressivo, porém, é permitida a mudança para um regime mais brando após o cumprimento de, no mínimo, um sexto da pena estabelecida na sentença condenatória e, ainda, que a conduta do apenado justifique a progressão. (GHISLENI, 2014). 
Ghisleni (2014, p. 194) explica que conforme o artigo 126 da LEP e a Súmula 341 do Superior Tribunal de Justiça, sobre a remição, reza que a frequência a curso de ensino formal é causa de remição de parte do tempo de execução de pena sob regime fechado ou semiaberto, isto é, o condenado pode remir, pelo trabalho e pelo estudo, parte de sua pena, na razão de três dias de trabalho/estudo para um dia de pena.

Diante do exposto, Ghisleni (2014) faz uma observação bastante importante no sentido de que apesar de todas as críticas que se fazem ao não cumprimento efetivo da lei de execução penal, ela se antecipou em relação ao pensamento das pessoas quando entrou em nosso ordenamento jurídico, o que é um grande progresso.

A autora citada continua seu pensamento e afirma que é muito presente em nossa sociedade o sentimento de vingança, o anseio de justiça na forma da lei de talião, na qual existe a rigorosa reciprocidade entre o crime e a pena aplicada. Sabemos, entretanto, que as normas jurídicas geralmente emanam de costumes do povo e não o contrário. O grande problema está justamente no fato de que as disposições da LEP, por mais adequadas e coerentes que sejam, acabam não se efetivando no plano prático, ficando apenas no patamar teórico.

Diante de tudo que foi exposto, reforça o pensamento que o estatuto da execução penal foi um episódio marcante no sistema penitenciário brasileiro, pois antes à Lei n.7210 de 1984 a execução da pena era somente um recurso administrativo, uma consequência legal e coerente da condenação. A Lei é avançada e elogiável, contudo, se transformou em vários aspectos, em escrita morta, pela inadimplência e absoluta omissão dos poderes instituídos na aquisição de soluções financeiras, humanas e materiais imprescindíveis à sua implantação. Para que aja aplicação correta da Lei e que ela não permaneça inviabilizada, há muito a que ser considerado.

\subsection{AS ATUAIS CONDIÇÕES DOS PRESÍDIOS BRASILEIROS}

Sobre a historicidade dos cárceres, Angotti (2018) explica que, na segunda metade do século XIX os cárceres nacionais eram masmorras insalubres, onde a violência, a fome e as doenças conviviam, cotidianamente, com os condenados e os guardas.

O autor citado explica que como solução, em um primeiro momento, as Casas de Correção, construídas a partir da década de 1850, representaram um passo importante para a mudança do quadro punitivo nacional, introduzindo a execução das penas com trabalho, voltadas àqueles para os 
quais havia sido prescrita, pelo juiz, pena laboral. Finalmente o condenado teria a possibilidade de, com o trabalho e as rígidas regras praticadas, ser corrigido e então voltar recuperado à sociedade.

Na literatura mostra que no cotidiano das casas de correção foi marcado por subversões e selvagerias, o que delongou o sonho de alguns de resolver os problemas prisionais e tornar o Brasil referência punitiva dentre os países civilizados. As Casas de Correção simulavam um empenho no sentido de oferecer ao aprisionamento uma função, que não meramente a de retirar o encarcerado do convívio social.

No Brasil, as Casas de Correção e as penitenciárias que as substituíram nasceram sob o debate de qual seria o modelo mais adequado aos cárceres nacionais. De um lado o isolamento completo previsto pelo sistema de Filadélfia e, por outro, o isolamento noturno com trabalho diário proposto pelo sistema de Auburn. Buscava-se conciliar a meditação com o trabalho, que deveria ser voltado antes para a disciplina que para o lucro. Conciliar trabalho, disciplina, silêncio, isolamento e oração poderiam ser uma boa fórmula para combater o crime e recuperar o criminoso. (ANGOTTI, 2018 p.101).

Ao passo em que a sociedade evoluía e se transformava, o sistema prisional viu a necessidade de adaptar-se a ela e as mudanças foram necessárias, conforme mostra o índice populacional carcerária na atualidade no quadro à seguir.

\section{QUADRO 1 - DADOS DA POPULAÇÃO EM CÁRCERE NO BRASIL}

País Brasil

\begin{tabular}{|l|l|}
\hline Ministério Responsável & Ministro da Justiça \\
\hline Administração Prisional & Departamento Penitenciário Nacional (DEPEN) \\
\hline Endereço de contato & $\begin{array}{l}\text { Esplanada dos Ministérios, Ministério da Justiça, Bloco T. Anexo } \\
\text { II, } 6^{\circ} \text { andar, Brasilia. }\end{array}$ \\
\hline Telefone & +55216134293187 \\
\hline
\end{tabular}




\begin{tabular}{|c|c|c|c|}
\hline Fax & +5 & -55216134299347 & \\
\hline Local na rede Internet & & ttp://depen.gov.br/DEPEN & \\
\hline Chefe da administração de Prisão (e titul & lo) $\mathrm{Ca}$ & Carlos Felipe Alencastro Fernandes & Carvalho - Diretor Geral \\
\hline $\begin{array}{l}\text { Total da população prisional (incluindo } \\
\text { presos provisórios / detidos em prisão } \\
\text { preventiva) }\end{array}$ & & $\begin{array}{l}\text { 20. } 888-\text { Em 26.7.2019 (Conselh } \\
\text { ste total omite presos mantidos er } \\
\text { oram detidos em 31.12.2016 }\end{array}$ & $\begin{array}{l}\text { Nacional de Justiça (CNJ) - } \\
\text { instalações policiais; } 19.735\end{array}$ \\
\hline $\begin{array}{l}\text { Taxa de população prisional (por } 100.00 \\
\text { da população nacional) }\end{array}$ & $\begin{array}{l}33 \\
\mathrm{~m} \\
\mathrm{U}_{\mathrm{r}}\end{array}$ & $\begin{array}{l}36 \text { - com base em uma populaçãa } \\
\text { nilhões no final de julho de } 2019 \text { ( } \\
\text { Jnidas) }\end{array}$ & $\begin{array}{l}\text { nacional estimada em } 214,59 \\
\text { partir de números das Nações }\end{array}$ \\
\hline $\begin{array}{l}\text { Prisioneiros preventivos / detidos em } \\
\text { prisão preventiva (porcentagem da } \\
\text { população carcerária) }\end{array}$ & & $4,1 \%-26.7 .2019$ & \\
\hline $\begin{array}{l}\text { Prisioneiras do sexo feminino } \\
\text { (porcentagem da população carcerária) }\end{array}$ & & $5 \% 9 \%$ - (Dezembro de 2016) & \\
\hline $\begin{array}{l}\text { Juvenis / menores / jovens reclusos } \\
\text { incl. definição (porcentagem da populaçã } \\
\text { carcerária) }\end{array}$ & ão 0, &, $0 \%-(30.6 .2017-$ sob 18$)$ & \\
\hline $\begin{array}{l}\text { Prisioneiros estrangeiros (porcentagem d } \\
\text { população carcerária) }\end{array}$ & & ,3\% (daqueles no sistema prisional, & $30.6 .17)$ \\
\hline \multicolumn{2}{|l|}{ Número de estabelecimentos / instituições } & \multicolumn{2}{|c|}{$\begin{array}{l}\text { 2. } 625 \text {-(28.2.2019 - De acordo com o Conselho Nacional de } \\
\text { Justiça) }\end{array}$} \\
\hline \multicolumn{2}{|l|}{ Capacidade oficial do sistema prisional } & \multicolumn{2}{|l|}{ 418. $895(31.5 .2019)$} \\
\hline \multicolumn{2}{|l|}{$\begin{array}{l}\text { Nivel de ocupação (com base na } \\
\text { capacidade oficial) }\end{array}$} & \multicolumn{2}{|l|}{$167,6 \%(31.5 .2019)$} \\
\hline \multirow{9}{*}{$\begin{array}{l}\text { Tendência da população carcerária } \\
\text { (ano, população total carcerária, taxa } \\
\text { de população carcerária) }\end{array}$} & 2000 & 232,755 & 132 \\
\hline & 2002 & 239,345 & 132 \\
\hline & 2004 & 336,358 & 180 \\
\hline & 2006 & 401,236 & 209 \\
\hline & 2008 & 451.429 & 231 \\
\hline & 2010 & 496,251 & 249 \\
\hline & 2012 & 548.003 & 270 \\
\hline & 2014 & 622,202 & 301 \\
\hline & 2016 & 726.712 & 347 \\
\hline
\end{tabular}

Fonte: World Prison Brief - 2019 https://www.prisonstudies.org/country/brazil

Segundo Braga et al. (2018) nas últimas décadas, o Brasil viveu um processo de crescimento exponencial da população penitenciária. De acordo com o último Levantamento Nacional de 
Informações Penitenciárias (INFOPEN, 2016) em junho de 2016, 726.712 pessoas estavam presas no País, elevando o Brasil ao posto de terceiro país com maior população carcerária no mundo (atrás apenas de Estados Unidos e China).

Ao consultar o sistema World Prison Brief é possível encontrar informações de todo o sistema penitenciário mundial, conforme tabela acima e, ao pesquisar sobre o cárcere brasileiro, nota-se que o país possui, em tese, 418. 895 (quatrocentos e dezoito mil e oitocentos e noventa e cinco) vagas. Entretanto, o número de pessoas encarceradas é de 720.888 (setecentos e vinte mil e oitocentos e oitenta e oito), sendo que a ocupação atinge 167,6\%, em 2019.

Em relação ao número de mulheres encarceradas, verifica-se que há 44.700 (quarenta e quatro mil e setecentos) prisioneiras femininas, ocupando $6,9 \%$ do total de pessoas encarceradas.

Sobre os direitos das mulheres em cárcere privado, de acordo com Wolff e Moraes (2010), estão muito longe da realidade perante as leis. $\mathrm{O}$ grande crescimento de mulheres presas por tráfico de drogas ou tipos penais afins não é uma realidade apenas do Brasil. Tais estudos indicam que o significativo índice de mulheres condenadas por tráfico de drogas está relacionado à questão de gênero, ocorrendo tanto pela dependência ao companheiro como pela necessidade de sustentar os filhos e a família.

Braga et al.(2018) alerta que o crescimento populacional e físico (número de unidades) do sistema não foi devidamente acompanhado da ampliação do número de servidores penitenciários e de oferta de serviços prisionais, tanto dos que compõem a equipe técnica multiprofissional quanto de agentes penitenciários, gerando um caos no sistema.

Outro entendimento neste sentido também se faz importante afirmar segundo Ghisleni (2014, p.200):

A superlotação dos estabelecimentos tornou as prisões e penitenciárias brasileiras verdadeiros depósitos humanos nos quais homens e mulheres são jogados sem o mínimo respeito a sua dignidade. Além disso, a alimentação é extremamente precária e são raros os estabelecimentos nos quais se pode afirmar haver os pressupostos mínimos inerentes a uma refeição digna. Raramente há uma preocupação no sentido de zelar pela dignidade/necessidade sexual dos apenados, o que acaba por comprometer significativamente o processo de cumprimento da pena.

Ante o já exposto, podemos entender o motivo pelo qual, segundo Batista (2017), as condições das penitenciárias no Brasil são extremamente preocupantes. Há inúmeras rebeliões, fugas, violência entre os presos, transmissão de doenças contagiosas, entre outros. Por outro lado, o que não ocorre dentro do sistema penitenciário são mecanismos eficazes na ressocialização do preso. Inegável que 
isto ocorre devido ao cenário degradante do sistema penitenciário brasileiro, que sujeita o condenado a condições demasiadamente precárias dentro da prisão.

Segundo Braga et al., (2018) ao lado da superlotação prisional e da crise permanente, que eclode em rebeliões, fugas e mortes, a insuficiência de equipes de saúde e de assistência judiciária figuram entre as principais mazelas dos sistemas prisionais estaduais. As administrações prisionais não têm sido capazes de conciliar e equilibrar as atividades de custódia e segurança com a provisão de saúde, alimentação, educação, trabalho e assistência jurídica para a população privada de liberdade, privilegiando a perspectiva do controle em detrimento das assistências previstas e garantidas pela Lei de Execução Penal.

Na realidade do nosso país vemos que esses direitos tendem a não ser cumpridos como deveriam fato este que é comprovado quando nos deparamos com unidades prisionais que apresentam falta de estrutura física, mobiliário insuficiente, muitas vezes precário, e falta de profissionais treinados e preparados para lidar com a saúde, principalmente a das gestantes (CARNEIRO, VERÍSSIMO, 2016 apud MOREIRA et al., 2018).

Batista (2017) elucida que em se tratando do sistema penitenciário brasileiro convém alegar que não é só o Estado que não exerce seu papel em relação às responsabilidades quanto à ressocialização do apenado no ambiente social, para dar-lhes de volta a dignidade merecida. Não é um acaso que os indicadores de reincidência criminal são alarmantes no país. É preciso saber se a sociedade está ou não preparada para receber esse ex-condenado.

Simas, Batista e Ventura (2018) reconhecem, sobre as mulheres em cárcere, que uma parcela delas não representa risco à sociedade, e seu encarceramento pode dificultar sua reinserção social, bem como, incentivam Estados a adotar legislações para estabelecer alternativas à prisão e a priorizarem o financiamento de tais sistemas.

De acordo com Braga et al., (2018) as recorrentes violações de direitos humanos na história e no presente em nossas prisões parecem indicar que as explosões violentas que ocorrem no sistema penitenciário são momentos pungentes de uma permanente tensão, sucateamento, vulnerabilidade e violência, que definem o funcionamento ordinário do sistema penitenciário no Brasil.

Conclui que, embora a Lei das Execuções Penais deva seguir rigorosamente as linhas esquematizadas pela Organização das Nações Unidas (ONU), o que se percebe que muitas mudanças são necessárias para se conseguir um patamar aceitável de cidadania nas prisões brasileiras. E uma das questões 
presumíveis e duradouras para minimizar o colapso no sistema prisional é que ocorram mudanças nas aplicações das penas, principalmente da pena privativa de liberdade, dando-a ao infrator somente em ocorrências específicas, de extremada necessidade, quando há verdadeiramente uma ameaça real a coletividade. Se o infrator não esteja enquadrado neste caso, então são aplicadas penas mais suaves como as pecuniárias e também laborais, conforme o que mais se destaca a habilidade do infrator. 0 que não pode continuar é a ociosidade do encarcerado e a inércia do Estado.

\subsection{O ESTADO DE COISAS INCONSTITUCIONAL NAS PRISÕES}

Pode ser definido o Estado de Coisas Inconstitucional como um termo/rótulo utilizado para a decretação de emergência e calamidade de alguma situação que esteja ocorrendo no país. Declarar que um determinado cenário trata-se de um estado de Coisa Inconstitucional é dizer que o caso está tão caótico e fora do controle que depende do abraçamento de todos os poderes, bem como, que todos os envolvidos assumam um compromisso real de resolver a questão de uma forma efetiva. (LIMA, 2015 apud Cavalcante, 2017).

Sobre o assunto George Marmelstein Lima (2015 apud Cavalcante, 2017) dispõe:

O conceito de ECl ("Estado de Cosas Inconstitucional") foi desenvolvido pela Corte Constitucional colombiana no contexto de violações sistemáticas de direitos fundamentais e possui um propósito bastante ambicioso: permitir o desenvolvimento de soluções estruturais para situações de graves e contínuas inconstitucionalidades praticadas contra populações vulneráveis em face de falhas (omissões) do poder público. Em termos muito sintéticos, ao declarar o Estado de Coisas Inconstitucional, o Judiciário reconhece a existência de uma violação massiva, generalizada e estrutural dos direitos fundamentais contra um grupo de pessoas vulneráveis e conclama que todos os órgãos responsáveis adotem medidas eficazes para solucionar o problema.

Lazari e Pires (2017) afirmam que no Brasil, o Supremo Tribunal Federal foi chamado a se manifestar pela primeira vez sobre o instituto do Estado de Coisas Inconstitucional na Arguição por descumprimento de Preceito Fundamental no 347/DF (medida cautelar), envolvendo a questão penitenciária pátria. Promovida pelo PSOL - Partido Socialismo e Liberdade, almejava-se na aludida manifestação de controle concentrado de constitucionalidade o reconhecimento da falência da política penitenciária pátria no que diz respeito à dignidade a ser assegurada aos cumpridores de penas.

Na petição inicial da Ação de Descumprimento de Preceito Fundamental 347, a ADPF 347 MC/DF, o constitucionalista da Escola Fluminense de Direito Constitucional elenca os seguintes requisitos para a configuração do estado de coisas inconstitucional conforme Fonteles (2018): 
“(i) vulneração massiva e generalizada de direitos fundamentais de um número significativo de pessoas; (ii) prolongada omissão das autoridades no cumprimento de suas obrigações para garantia e promoção dos direitos; (iii) a superação das violações de direitos pressupõe a adoção de medidas complexas por uma pluralidade de órgãos, envolvendo mudanças estruturais, que podem depender da alocação de recursos públicos, correção das políticas públicas existentes ou formulação de novas políticas, dentre outras medidas; e (iv) potencialidade de congestionamento da justiça, se todos os que tiverem os seus direitos violados acorrerem individualmente ao Poder Judiciário".

Seguindo esse raciocínio, Andrade e Cambi (2019) esclarece que foi reservado ao Supremo Tribunal Federal o papel de ordenação do caos do sistema carcerário, ao julgar a Medida Cautelar da ADPF 347, e o STF reconheceu o Estado de Coisas Inconstitucional, consistente no desrespeito crônico e massivo dos direitos fundamentais, ocasionados essencialmente por falhas estruturais e a falência de políticas públicas. Em sede preliminar, a Corte afirmou que tal fato só será modificado com medidas de natureza normativa, administrativa e orçamentária.

\begin{abstract}
"O quadro de violação massiva a direitos fundamentais e a falência de políticas públicas são permeadas por uma cultura punitiva por meio da qual é muito mais fácil sustentar, por exemplo, que a pessoa privada de sua liberdade que queima o próprio colchão deve dormir no chão ou, ainda, que "bandido bom é bandido morto", do que reconhecer parcela de culpa da sociedade pela deterioração do tecido social. Cultura em que a saída temporária equivocadamente generalizada por alguns órgãos da imprensa de indulto, é tratada como a causa da insegurança, e não como mecanismo apto a oxigenar o ambiente prisional". (SANTOS; ÁVILA, 2017).
\end{abstract}

Sobre a responsabilidade da Medida Cautelar da ADPF 347, Fonteles (2017) explica que em nome da concretização de direitos fundamentais, obstaculizados por uma inércia qualificada como falha estrutural, o Judiciário assume o protagonismo de políticas públicas. A decisão, que reconhece a realidade inconstitucional, determina um conjunto de providências para combatê-la, coordenando-as e monitorando o bom cumprimento das medidas. Na prática, a técnica transforma o órgão judicante em um coordenador institucional.

A explicação de Cavalcante (2017) sintetizada sobre a ECl é a seguinte: a ideia é fazer com que os incumbidos assumam suas atribuições e adotem medidas, dentro de suas competências, visando à solução da questão. Para isso, ao declarar o ECl e identificar o grave e eminente problema e a consequente violação de direitos fundamentais, a primeira medida adota pelo judiciário é a comunicação às autoridades, depois, convoca-se órgãos responsáveis para que elaborem planos de saída, bem como, que haja a indicação de órgãos de monitoramento e fiscalização sob as medidas adotadas. 
Lazari e Pires (2017) elucida que o Estado de Coisas Inconstitucional não se assemelha às ações diretas de inconstitucionalidade, por exemplo, porque não se fixam em um dado caso ou uma dada inconstitucionalidade de determinada lei, emenda ou ato normativo, mesmo que de forma abstrata. É mais que isso. Parte, sim, de uma visão generalizada do problema, o qual tem expressão mais caótica e que afeta a todos no Estado de Direito, direta ou indiretamente.

Fonteles (2018) esclarece que não há consenso entre os estudiosos acerca dos requisitos para a configuração do estado de coisas inconstitucional. Nas palavras do Eminente Min. Marco Aurélio, extraídas do voto proferido na ADPF $347 \mathrm{MC} / \mathrm{DF}$, existem três principais pressupostos para a configuração do estado de coisas inconstitucional:

\footnotetext{
"situação de violação generalizada de direitos fundamentais; inércia ou incapacidade reiterada e persistente das autoridades públicas em modificar a situação; a superação das transgressões exigir a atuação não apenas de um órgão, e sim de uma pluralidade de autoridades".
}

O autor citado afirma que Daniel Sarmento, por sua vez, além dos três requisitos apontados pelo Min. Marco Aurélio, acrescenta um quarto requisito, qual seja, a "potencialidade de congestionamento da justiça". Ele reforça "ora, com a devida vênia, a potencialidade de assoberbar o Judiciário é consequência natural e implícita na violação em massa de direitos fundamentais, afinal, se a ofensa foi generalizada, o risco demandista é iminente, porque haverá uma demanda represada".

Busato e Cavagnari (2018) elucidam que o Supremo Tribunal Federal julgou dois casos de extrema relevância sobre o tema da execução penal, por meios dos quais atestou, pela via jurisprudencial, o caos no sistema penitenciário. O primeiro, julgado em 2015, foi a decisão na ADPF 347/DF, em que o Plenário da Corte Suprema reconheceu expressamente do $\mathrm{ECl}$ no sistema penitenciário brasileiro. $\mathrm{O}$ segundo, julgado em 2016, foi a decisão no Recurso Extraordinário 641.320/RS, em que o Plenário da Corte Suprema acentuou o entendimento de que o preso em regime semiaberto, diante da ausência de vagas derivadas da responsabilidade do Estado, deve ser submetido ao regime domiciliar monitorado por tornozeleira eletrônica.

Em se tratando da maternidade nas prisões, Andrade e Cambi (2019), diante da declaração do Estado de Coisas Inconstitucional do Sistema Carcerário brasileiro, consignado na ADPF MC/DF, Rel. Min. Marco Aurélio, julgado em 09/09/2015, com manifesta violação de direitos fundamentais básicos, não se concebe que grande parte dos estabelecimentos prisionais estejam atendando as normativas internacionais que ampliaram a proteção dessa classe de mulheres que demandam especial atenção. 
Revelado um cenário prisional que foi pensado e destinado ao público masculino que na maior parte das vezes é apenas adaptado às mulheres, não dispondo de infraestrutura básica para higienização, atendimento médicohospitalar e, especialmente, não sem fornecendo subsídios mínimos para a realização da maternidade, observa-se a maior gravidade do que o Supremo Tribunal Federal reconheceu como Estado de Coisas Inconstitucional do Sistema Carcerário.

Os autores citados elucidam que não se está a defender que caiba ao Poder Judiciário a implementação de políticas públicas para a humanização do sistema penitenciário, mas precisa assumir a responsabilidade no reconhecimento do problema de modo a buscar soluções balizadas com os direitos humanos-fundamentais. Se a liberdade é um direito fundamental relativo ante a imposição da sanção penal, essa relativização não deve permitir penas materialmente cruéis e transcendentes, atingindo a apenada e o nascituro/infante.

Andrade e Cambi (2019) concluem que:

há uma crise instalada no sistema carcerário, motivo pelo o qual é correto o diagnóstico do STF, na ADPF 347, ao reconhecer um Estado de Coisas Inconstitucional; há um vertiginoso encarceramento feminino ocasionado, sobretudo, pelo delito de tráfico de drogas; o aprisionamento (seja ele definitivo ou provisório), na grande maioria das prisões brasileiras, não se revela adequado quando se está a falar de mulheres grávidas, notadamente porque há uma verdadeira pena cruel em virtude das condições precárias das unidades prisionais; as gestantes presas vivem dentro do cárcere dois fenômenos, a saber, a hipermaternidade e a hipomaternidade; a manutenção da gestante nas unidades prisionais, em situações desumanas, fere o direito fundamental contido no art. 5ㅇ, XLV, CF/88 (LGL\1988\3); a prisão domiciliar contida na Lei de Execuções Penais precisa ser readequada de modo a atender a materialização da maternidade; cabe ao integrantes do sistema de justiça (advogados, membros do Ministério Público e juízes) levar em conta as questões de gênero e as circunstâncias especiais das gestantes/mães/lactantes e seus filhos - em âmbito nacional ou internacional - para que se produzam decisões protetivas aos direitos humanos.

Deste modo, as normas (em sentido amplo) internacionais introduzidas no Brasil não só podem como devem ser invocadas para o problema assinalado. É de suma importância que a decisão judicial também observe às questões de gênero e, sobretudo, as circunstâncias da maternidade que se mostra restrita, solapada e violada no cárcere. Somente o respeito ao duplo limite vertical (constituição, os tratados de direitos humanos e tratados comuns) conduzirão ao respeito à dignidade humana nas penitenciárias femininas. (ANDRADE; CAMBI, 2019).

Pode-se notar que, para se constituir uma situação do estado de coisas inconstitucional há varias considerações para alguns autores, e para determinadas pessoas isso é bem resumido. Em uma análise sintetizada conclui-se que ela deva existir principalmente na circunstância de transgressão 
generalizada de direitos fundamentais; inércia ou inaptidão constante das autoridades notórias em transformar a ocasião; na superioridade das contravenções e estabelecer o envolvimento não exclusivamente de um órgão, e sim de uma variedade de autoridades.

\title{
3. A MATERNIDADE NO CÁRCERE E A PRISÃO DOMICILIAR
}

O objetivo deste capítulo é conseguir um julgamento acerca dos aspectos que abarcam a maternidade no ambiente do cárcere, levando em conta os momentos da gravidez, do parto, da amamentação, da convivência entre mãe e filho dentro da prisão, da prisão domiciliar e do momento da separação. Logo após, as considerações sobre o assunto.

\subsection{A SITUAÇÃO ESPECÍFICA DAS MULHERES NO CÁRCERE}

Muito se vem discutindo sobre diversos assuntos polêmicos envolvendo os presídios brasileiros. Temas como a superlotação, as visitas íntimas, as drogas lícitas e ilícitas trocadas nos corredores, o uso indevido e proibido dos celulares, a situação precária das infraestruturas.

De acordo com a autora Ronchi (2017) sobre as mulheres no cárcere ela faz uma análise:

\begin{abstract}
a prisão feminina deve ser estudada de forma apartada da prisão masculina, pois possui diversas peculiaridades inerentes à condição de ser mulher, sendo a principal delas a questão da maternidade. A situação da vivência dentro do presídio, que já é precária para as mulheres em geral, agrava-se consideravelmente quando envolve a maternidade: durante a gestação elas não têm à sua disposição estrutura apropriada e assistência médica especializada, entre diversos outros problemas. Sendo que, quando os filhos nascem, a situação se torna ainda mais alarmante, pois se acaba transferindo as dificuldades de estar encarcerado para um terceiro, criando uma situação de condenação extensiva, na qual o princípio constitucional da personalidade da pena é violado.
\end{abstract}

O que se nota é que na maioria os presídios masculinos são o foco, e os presídios femininos que precisam ter um olhar diferenciado, já que estão ali são mulheres que engravidam, se tornam mães, amamentam, menstruam; é percebido que o assunto é restrito.

\subsubsection{UM BREVE HISTÓRICO SOBRE O SURGIMENTO DOS PRESÍDIOS FEMININOS}

Angotti (2018) relata que desde o período colonial, no Brasil, as mulheres foram encarceradas em estabelecimentos onde prevaleciam prisioneiros do sexo masculino, sendo a elas raramente destinados espaços reservados. Prostitutas e escravas, em sua maioria, as mulheres eram confinadas junto aos homens, frequentemente dividindo a mesma cela. Narrativas de abandono, abusos sexuais, problemas com a guarda - na maioria das vezes masculina -, doenças, promiscuidade e outros, 
envolvendo as mulheres encarceradas, estavam sempre presentes nos trabalhos de penitenciaristas do século XX.

Gadelha (2016) vem confirmar essas declarações e afirma que na historicidade, na maioria das literaturas, percebe-se que o tema das mulheres presas entrou em pauta, a partir de meados do século XIX, quando a precariedade da situação prisional brasileira começou a ser explicitada e diferentes profissionais passaram a se dedicar a buscar soluções para resolvê-la. Relatos esparsos e alguns relatórios de diferentes períodos mostram a situação das encarceradas nas prisões e casas de correção brasileiras.

Angotti (2018) declara que apesar do debate sobre os presídios femininos no país ser pauta da discussão carcerária desde as últimas décadas do século XIX, foi somente na década de 1940 que os estabelecimentos prisionais só para mulheres foram criados em alguns estados brasileiros.

Angotti (2018) acredita que com a urgência em separar homens de mulheres e diminuir o atraso dos cárceres nacionais rumo à superação do paradigma da prisão-masmorra explica as inúmeras adaptações que acompanharam a criação dos primeiros estabelecimentos prisionais femininos brasileiros. A adaptação dos prédios, a escolha da opção mais prática e menos custosa para a administração, a falta de um projeto penitenciário claro - apesar do tema ser pauta antiga -, fez com que os presídios femininos nascessem no país de maneira improvisada.

Ronchi (2017) ressalta a importância da participação fundamental da Congregação de Nossa Senhora Caridade do Bom Pastor D'Angers, irmandade que participou ativamente do processo de construção dos presídios femininos no Brasil, através de sua administração e contato com as detentas.

A autora citada continua afirmando que o Instituto Bom Pastor de Angers, que foi fundado na França em 1829 e tinha como objetivo principal "[...] acolher jovens e mulheres com ou sem filhos, excluídas e/ou em situação de risco, e ir ao encontro de pessoas e famílias em idênticas situações, como colaboradoras da Missão Redentora da Igreja", via na prisão um local onde as mulheres teriam uma segunda chance para se redimir de seus pecados através da oração e do amor.

Em 1891 as Irmãs fundaram sua primeira casa em território brasileiro, no Rio de Janeiro e, com o passar do tempo, continuaram a expandir para outras cidades. Em 1924 a Congregação começou a atuar no campo criminal e passaram a atuar como administradoras dos presídios femininos, começando com o Reformatório para Mulheres de Porto Alegre. (RONCHI, 2017). 
Angotti (2018) afirma que a estrutura da prisão também era algo em discussão. Havia os requisitos para a estrutura ideal, descritas nas instruções da construção da penitenciária de Bangu, a única projetada para mulheres; dentre eles destaca-se: o investimento em um modelo penitenciário misto, com trabalho agrícola; espaço para abrigar, no mínimo, sessenta condenadas e vinte processadas; isolamento entre processadas e condenadas e espaço para abrigar crianças e suas mães, especialmente no período de amamentação.

Aqui se nota a preocupação das mães em cárcere e o destino dos seus filhos. Ronchi (2017) declara que já se atentava com a questão da maternidade exercida dentro do ambiente prisional e de que forma seria melhor conciliar o ambiente prisional com a vida e desenvolvimento de uma criança.

A primeira penitenciária feminina no Brasil é construída então e de acordo com Gadelha (2016) e foi fundada pelas freiras em Porto Alegre. Chamada de Penitenciária Madre Pelletier começou abrigando não só criminosas, mas mulheres que não se adequavam de alguma forma à sociedade, as ditas "desajustadas".

Souza (2018) concorda afirmando que em 1940 entrou em vigor a reforma do Código Penal, marco importante para o Direito Penal nacional que, pela primeira vez, previu o cumprimento de pena em estabelecimento diferenciado para abrigar mulheres surgindo assim, a prisão feminina no Brasil, diferente do surgimento do encarceramento feminino, que como fora visto, surgiu pela perseguição moral e religiosa da Igreja.

Souza (2018) ressalta a importância dessas unidades prisionais diferenciadas e que foram idealizadas por Lemos de Brito, que após analisar todas as prisões do Brasil em visitas, aconselhou a União a construir um espaço especial, que não se pautava nos moldes da época, elaborado por homens para homens, mas sim destinado ao abrigo de mulheres.

Lemos de Brito foi encarregado, no começo 1923, pelo então ministro da Justiça João Alves, a elaborar um projeto de reforma penitenciária. Para tanto, percorreu o país visitando todas as prisões e ofereceu um plano geral, em 1924, no qual aconselhou a União a construir um reformatório especial (em pavilhão completamente isolado) não somente para as mulheres condenadas há mais de três anos do Distrito Federal, mas às que forem remetidas pelos estados. Cabe observar que Lemos de Brito não sugeriu a construção de uma prisão nos moldes tradicionais da época, ou seja, não se pautou pelo modelo das prisões masculinas. Ele propôs, ao invés disso, a construção de um reformatório especial, com o que indicava a necessidade de um tratamento específico para a mulher por parte do Sistema Penitenciário. (SOARES; ILGENFRITZ, 2002 apud SOUZA, 2018). 
Vale ressaltar aqui a importância também das ordens religiosas que teve evidência no cenário das políticas públicas penitenciárias do Brasil, na primeira metade do século XX e que se mostram ainda atuantes, mais de uma forma diferente. Gardelha (2016) afirma que na atualidade, a Madre Pelletier, apesar de ainda possuir uma estrutura precária, acomoda presas que cozinham sua própria comida e até possuem um salão de beleza. Cerca de noventa por cento de suas detentas estudam ou trabalham.

\subsubsection{DADOS DO PERFIL DA MULHER ENCARCERADA NO BRASIL}

Todos os dados expostos abaixo foram coletados do Infopen 2018, sendo este de grande valia para nossa pesquisa, vez que traça o perfil da mulher encarcerada no Brasil e temos os seguintes dados:

Tabela 1. Mulheres privadas de liberdade no Brasil em Junho de 2016

\begin{tabular}{|l|l|}
\hline \multicolumn{2}{|c|}{ Brasil - Junho de 2016 } \\
\hline População prisional feminina & 42.355 \\
\hline Sistema Penitenciário & 41.087 \\
\hline $\begin{array}{l}\text { Secretarias de Segurança// Carceragens de } \\
\text { delegacias }\end{array}$ & 1.268 \\
\hline Vagas para mulheres & 27.029 \\
\hline Déficit de vagas para mulheres & 15.326 \\
\hline Taxa de ocupação & $156,7 \%$ \\
\hline Taxa de aprisionamento & 40,6 \\
\hline
\end{tabular}

Fonte: Levantamento de Informações Penitenciárias- INFOPEN, Junho/2016

A tabela acima apresenta dados de um levantamento de várias informações sobre as penitenciárias, principalmente as femininas no Brasil, conforme dados do INFOPEN de junho de 2016:

o panorama da população prisional feminina registrada em 30/06/2016 estava em 1.418 unidades prisionais, distribuídas entre estabelecimentos penais masculinos, femininos e mistos do sistema penitenciário estadual. As unidades que participaram do levantamento somam 27.029 vagas disponibilizadas para mulheres, o que compõe uma taxa de ocupação de $156,7 \%$ e um déficit global de 15.326 vagas, somente entre mulheres. Se considerarmos os dados populacionais globais, teremos, em Junho de 2016, uma taxa de 40,6 mulheres presas no Brasil para cada grupo de 100 mil mulheres. E podemos afirmar que existem 41.087 mulheres privadas de liberdade nos estabelecimentos penais que compõem o sistema prisional estadual. (DEPEN, 2017).

No contexto internacional, de acordo com os dados da INFOPEN, sobre os países com maior população feminina em cárcere temos: 
Tabela 2. Informações dos doze países com maior população prisional feminina do mundo

\begin{tabular}{|l|l|}
\hline \multicolumn{1}{|c|}{ País } & \multicolumn{1}{|c|}{$\begin{array}{c}\text { População Prisional } \\
\text { Feminina }\end{array}$} \\
\hline Estados Unidos & 211.870 \\
\hline China & 107.131 \\
\hline Rússia & 48.478 \\
\hline Brasil & 42.355 \\
\hline Tailândia & 41.119 \\
\hline Índia & 17.834 \\
\hline Filipinas & 12.658 \\
\hline Vietnã & 11.644 \\
\hline Indonésia & 11.465 \\
\hline México & 10.832 \\
\hline Mianmar & 9.807 \\
\hline Turquia & 9.708 \\
\hline
\end{tabular}

Fonte: Elaboração com dados DEPEN, 2017.

O nosso país se depara na quarta colocação no ranking mundial, entre os doze países que mais enclausuram pessoas femininas no mundo, estando atrás apenas da China, Estados Unidos, e da Rússia em semelhança ao tamanho integral de sua população prisional feminina, conforme a tabela 2 apresentada acima.

Em síntese, em similaridade ao percentual de aprisionamento, que declara o apontador de indivíduas encarceradas para cada grupo de 100 mil mulheres, o Brasil figura na terceira posição.

Se observar em série histórica a evolução da taxa de aprisionamento nos cinco países que mais encarceram mulheres no mundo, é possível observar que a expansão do encarceramento de mulheres no Brasil não encontra parâmetro de comparabilidade entre o grupo de países. Em um período de 16 anos, entre 2000 e 2016, a taxa de aprisionamento de mulheres aumentou em $455 \%$ no Brasil. No mesmo período, a Rússia diminuiu em $2 \%$ o encarceramento deste grupo populacional. (DEPEN, 2017).

De acordo com os dados do Depen (2017), em Junho de 2016, o total do mulheril encarcerado alcançou a quantidade de 42 mil delas, o que comprova um acréscimo de $656 \%$ em semelhança ao total apontado no começo dos anos 2000, quando abaixo de 6 mil mulheres se deparavam presas.

A partir da análise da amostra de mulheres sobre as quais foi possível obter dados acerca da idade, podemos afirmar que $50 \%$ da população prisional feminina são formadas por jovens, consideradas até 29 anos, segundo classificação do Estatuto da Juventude (Lei no 12.852/2013). Mas a informação sobre faixa etária da população prisional feminina estava disponível somente para 30.501 mulheres (ou 74\% da população feminina total). (DEPEN, 2017). 


\title{
Gráfico 2. Faixa etária das mulheres privadas de liberdade no Brasil
}

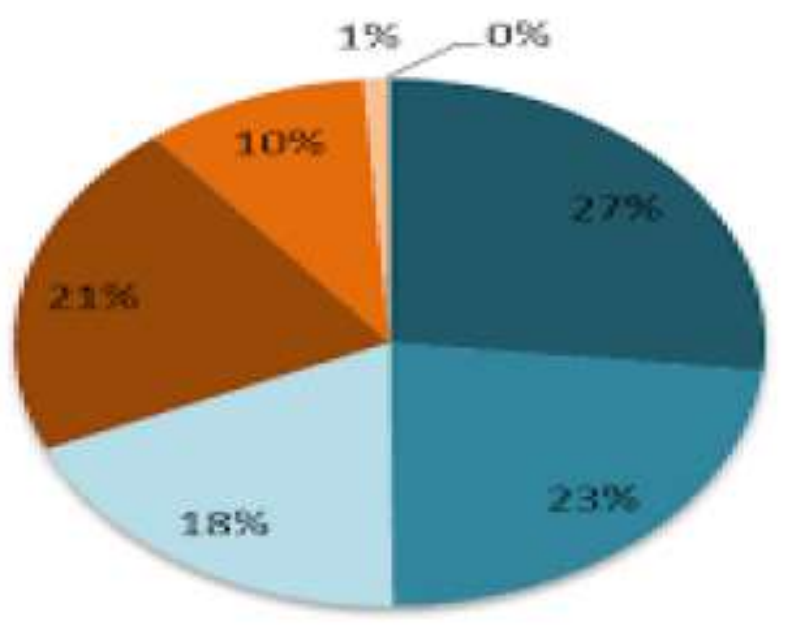

\author{
in 18 a 24 anos \\ - 25 a 29 anos \\ 30 a 34 anos \\ = 35 a 45 anos \\ in 460 anos \\ 41. a 70 anos \\ Mais de 70 anos
}

Fonte: Levantamento de Informações Penitenciárias - INFOPEN, Junho/2016.

De acordo com as pesquisa é possível verificar que as chances de mulheres entre 18 e 29 anos estarem encarceradas no Brasil é 2,8 vezes maior do que as chances de mulheres com 30 anos ou mais serem presas; e se tratando de aprofundar a análise acerca do aprisionamento em diferentes faixas etárias da população criminalmente imputável, algumas informações sobre a escolaridade são alarmantes.

Existem 101,9 jovens (de18 a 29anos) presas para cada 100.000 mulheres brasileiras com mais de18 anos, enquanto que a taxa de mulheres com 30 anos ou mais (não jovens) presas é equivalente a 36,4 para cada grupo de 100 mil mulheres acima de 18 anos. Foram obtidas informações acerca da escolaridade para $73 \%$ da população feminina privada de liberdade no Brasil (ou 29.865 mulheres). $14,66 \%$ da população prisional feminina ainda não acessou o ensino médio, tendo concluído, no máximo, o ensino fundamental. Apenas $15 \%$ da população prisional feminina concluiu o ensino médio. (DEPEN, 2017).

Em relação ao estado civil da população prisional, foi possível obter informações para $62 \%$ da totalidade de indivíduas coibidas de liberdade (o que equivale a 25.639 mulheres).

Sobre os tipos de delitos têm-se: 


\section{Gráfico 3 - Tipos de Delitos - População Feminina no Brasil Tipos de Delitos - População Feminina}

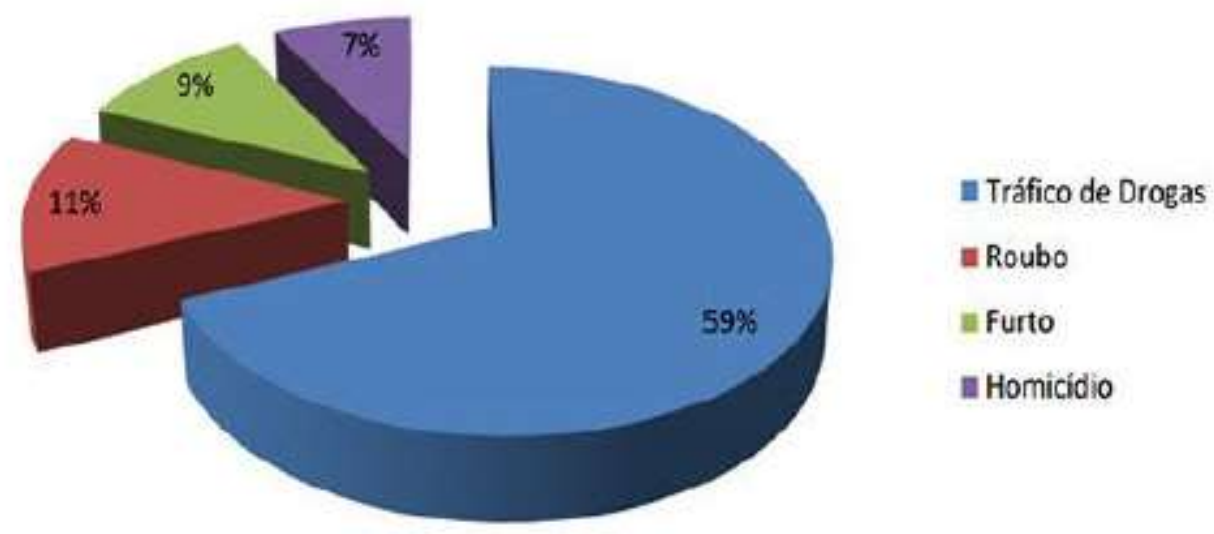

Fonte: Levantamento de Informações Penitenciárias - INFOPEN, Junho/2016.

Conforme Souza (2018) explica que do total de mulheres aprisionadas, temos que grande parte comete crimes que não são de grande periculosidade, sendo 59\% destas encarceradas em razão de cometimento de tráfico de drogas, crime que por ser equiparado a hediondo, não permite que estas obtenham penas alternativas e não permite também o recebimento de indulto.

A autora citada elucida que

esse aumento da população carcerária está diretamente ligada, a emancipação da mulher e sua maior participação na vida em comunidade, estas que por muitas vezes são chefes de famílias e por não possuírem estudos e condições de conquistar empregos, acabam recorrendo ao mundo do crime como solução do sustento familiar ou até mesmo, como meio de complementação de renda (SOUZA, 2018).

Sobre os direitos das mulheres em cárcere privado, de acordo com Wolff e Moraes (2010), estão muito longe da realidade perante as leis. $\mathrm{O}$ grande crescimento de mulheres presas por tráfico de drogas ou tipos penais afins não é uma realidade apenas do Brasil. Tais estudos indicam que o significativo índice de mulheres condenadas por tráfico de drogas está relacionado à questão de gênero, ocorrendo tanto pela dependência ao companheiro como pela necessidade de sustentar os filhos e a família. 


\section{Gráfico 4 - Frequência das visitas nas prisões femininas no Brasil Frequência com que recebe visitas}

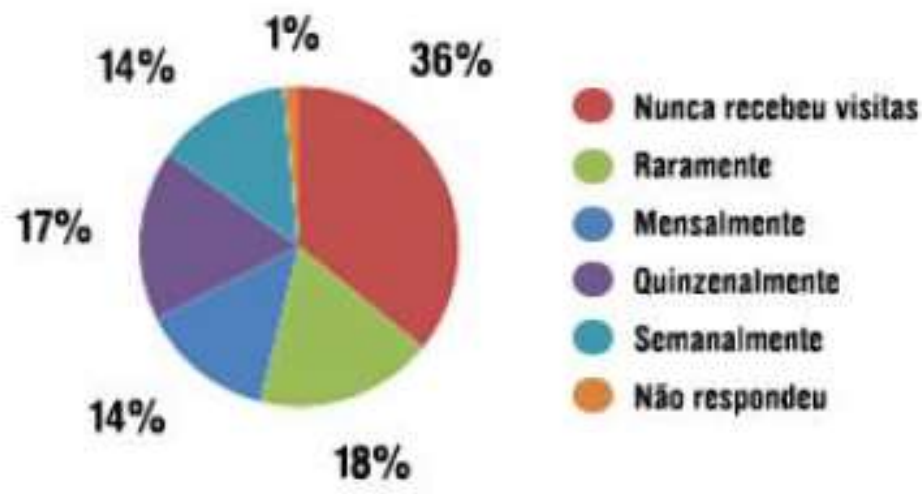

Fonte: Levantamento de Informações Penitenciárias - INFOPEN, Junho/2016.

Encontra-se entre os direitos da pessoa presa, o direito a receber visita do esposo, da consorte, de parentes e amigos em oportunidades definidas pela autoridade responsável. Essas regras são recomendadas no artigo 41 da Lei de Execução Penal.

Para que o direito à visita social seja garantido, as unidades prisionais devem contar com ambiente destinado à realização da visita - e eventualmente a outras atividades sociais -, diversos do ambiente de pátio de sol e celas das pessoas privadas de liberdade. Ao analisar a distribuição destes ambientes entre as unidades prisionais que abrigam mulheres no Brasil (estabelecimentos femininos e mistos), verifica-se que 1 em cada 2 unidades femininas não contam com espaços nestas condições e, no caso das unidades mistas, apenas 3 a cada 10 estabelecimentos contam com infraestrutura adequada ao exercício do direito à visita social da pessoa presa. (DEPEN, 2017).

Souza (2018) salienta que é percebido o abandono duplo sofrido por essas mulheres, sendo o primeiro deles cometido muitas vezes por seus familiares e companheiros, e o segundo realizado por parte do Estado, que negligencia toda e qualquer necessidade feminina no cárcere, tornando a estadia dessas mulheres na prisão cruel e desumana, sem a presença de artigos básicos e sem políticas estatais que visam contribuir para a não reincidência na vida do crime. 


\section{Gráfico 5 - Raça, cor ou etnia das mulheres privadas de liberdade}

\section{Sistema Prisional}

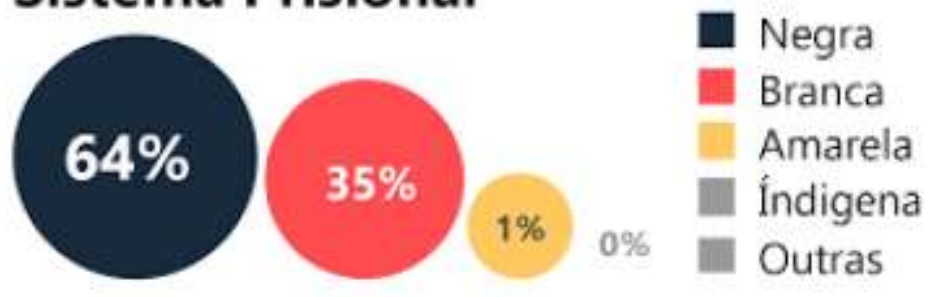

Fonte: Levantamento de Informações Penitenciárias - INFOPEN, Junho/2016.

Conforme o estudo do diagnóstico da amostra de mulheres foi provável alcançar informações acerca da raça, cor ou etnia pode-se afirmar que $64 \%$ da população em cárcere feminino é determinado por mulheres negras.

\footnotetext{
Pode-se afirmar que, entre a população maior de 18 anos, existem aproximadamente 35 mulheres brancas privadas de liberdade para cada grupo de 100 mil mulheres brancas, e existem 64 mulheres negras na mesma situação para cada grupo de 100 mil mulheres negras, o que expressa a disparidade entre os padrões de encarceramento de mulheres negras e brancas no Brasil. A informação sobre a raça, cor ou etnia da população prisional feminina estava disponível para 29.584 mulheres (ou $72 \%$ da população prisional feminina). (DEPEN, 2017).
}

Sobre as mulheres que trabalham dentro das penitenciárias, há um cálculo de $30 \%$ (6.766) da população carcerária feminina. Porém, a superioridade (75\%) o faz nos recintos internos da prisão, enquanto apenas $25 \%$ arrumam vagas em lugares externos. Já no que tange à educação uma percentagem mais insignificante domina as unidades penitenciárias, perto de $25,3 \%$ (5703) da população presidiária feminina deparam-se em atividades educativas formais e complementares, enquanto somente $8,8 \%$ delas estariam trabalhando e estudando. (DEPEN, 2017).

\subsubsection{ESTUDOS SOBRE OS DIREITOS DAS ENCARCERADAS NO BRASIL}

Em relação especificamente ao aprisionamento feminino, pode ser notado um esforço nas politicas públicas, pois foram criadas o "Grupo de Trabalho Interministerial sobre mulheres presas e egressas", instituído pela portaria no 885, de 22 de maio de 2012, do Ministério da Justiça; assim como a "Política Nacional de Mulheres em situação de privação de liberdade e egressas do Sistema Prisional", instituída pela portaria Interministerial no 210 de 16 de Janeiro de 2014. Pode-se afirmar que, de forma ainda lenta, e certamente tardia, as mulheres presas vêm ganhando certa visibilidade e representação em políticas e pesquisas. 
(BRASIL, 2014).

Um estudo importante sobre as condições das mulheres presas foi iniciado por Nana Queiroz e depois foi intitulada como "presos que menstruam". Ela penetrou no sistema carcerário de mansinho e fez laços com famílias das detentas, trocou carta com elas, se apresentou para tarefas voluntárias, acampou nas instituições penitenciárias. Assim, ela obteve entrevistas com presidiárias em todas as regiões do país. Na região norte, elegeu o Pará, no centro-oeste Brasília, no nordeste a Bahia, na região sul Rio Grande do Sul, e no sudoeste São Paulo.

A pesquisa, que iniciou em 2010, se desdobrou até 2015. E é por meio desses depoimentos que Nana exibe a precariedade a que as encarceradas estão sujeitas. Também conversou com voluntárias, psicólogas, pedagogas e assistentes sociais, perfazendo um panorama da situação carcerária feminina no Brasil.

Durante essas viagens ao submundo, descobri que não era apenas o governo que nos impedia de falar sobre o assunto. Tabus são mantidos, também, pelos que se recusam a falar sobre eles. E nós, enquanto sociedade, evitamos falar de mulheres encarceradas. Convencemos a nós mesmos de que certos aspectos da feminilidade não existirão se nós não os nomearmos ou se só falarmos deles bem baixinho. Assim, ignoramos as transgressões de mulheres como se pudéssemos manter isso em segredo, a fim de controlar aquelas que ainda não se rebelaram contra o ideal da "feminilidade pacífica". Ou não crescemos ouvindo que a violência faz parte da natureza do homem, mas não da mulher? É fácil esquecer que mulheres são mulheres sob a desculpa de que todos os criminosos devem ser tratados de maneira idêntica. Mas a igualdade é desigual quando se esquecem das diferenças. São pelas gestantes, os bebês nascidos no chão das cadeias e as lésbicas que não podem receber visitas de suas esposas e filhos que temos que lembrar que alguns desses presos, sim, menstruam. (QUEIROZ, 2015, pag. 18-19).

Outros estudos também foram feitos, Sá, Simões e Bartolomeu (2019) destacam o que no ano de 2014, o projeto Mulheres pelas Mulheres iniciou suas atividades. O inconformismo com a situação do sistema penitenciário, numa perspectiva de violência estrutural, e diante da invisibilidade das mulheres encarceradas, fez com que o Mulheres pelas Mulheres, em março daquele ano, realizassem seu primeiro Mutirão Carcerário nas unidades prisionais femininas do Paraná, situadas em Curitiba, Pinhais e Piraquara, com o objetivo principal de ouvir e dar voz a mulheres esquecidas e silenciadas, com o intuito também político de questionar o Dia Internacional da Mulher.

As autoras esclarecem que a intervenção das integrantes do projeto revelou que a precária alimentação e as péssimas condições de higiene, associadas ao abandono afetivo e emocional, não eram as únicas mazelas a afetar as mulheres dentro dos muros do sistema prisional. 
Elas continuam afirmando que, muitas das internas viviam, também, um hiato jurídico: a grande maioria não possuía defesa constituída, muitas desconheciam o andamento de seus processos e, em alguns casos, era mesmo difícil identificar o real motivo que as tinha levado à prisão. Fato que se somava ao completo apagamento social e familiar, decorrência dos castigos impostos pela heteronormatividade que ultrapassam as próprias penas.

Souza (2018) explica que o Estado é responsável por garantir e proporcionar condições mínimas de vida aos seres humanos que cumprem penas privativas de liberdade. Apesar de o indivíduo estar preso, o único direito que lhe é privado, é o direito de ir e vir e, portanto, os demais direitos para os transgressores da lei devem persistir, necessitando-se que a integridade física e moral dos mesmos sejam mantidas.

Souza (2018) esclarece que há a proibição de tortura, tratamentos ou punições cruéis, degradantes ou desumanos, conforme pactos assinados pelo Brasil, como o Pacto Internacional sobre Direitos Civis e Políticos, a Convenção contra a Tortura e Outros Tratamentos ou Penas Cruéis, Desumanas ou Degradantes e a Convenção Americana sobre Direitos Humanos, Pacto São José da Costa Rica, que tem como objetivo a ressocialização do condenado, sendo esta a finalidade do encarceramento.

Souza (2018) explica que nos dias atuais o cárcere continua sendo um local completamente excludente e despersonalizador, as mulheres entram nas unidades prisionais e são obrigadas a deixarem a sua personificação de lado, passam a vestir as mesmas roupas e têm de seguir as mesmas ordens, deixando para fora todas as outras atribuições e funções da sua vida particular, passando a ser identificada e estigmatizada apenas como mulher aprisionada.

\subsubsection{A INTIMIDADES DAS PRESAS}

Sobre a intimidade dos presos, é possível observar que, ainda que formalmente garantido, o exercício do direito à visita íntima, com observância à dignidade e privacidade do indivíduo preso, ele se depara com limitações determinadas pela infraestrutura dos locais penais. Em se tratando das unidades femininas, $41 \%$ dos estabelecimentos contam com local específico para consumação da visitação íntima e, no caso dos locais compostos, somente $34 \%$ das unidades podem oferecer este espaço às pessoas privadas de liberdade. (DEPEN, 2017). 
Entre os direitos estabelecidos na LEP, encontra-se ainda o exercício da visita íntima, garantida aos presos de ambos os sexos recolhidos em estabelecimentos prisionais. Fundamentado no princípio da igualdade de direitos, foi reformulado para assegurar o direito à visita íntima "às pessoas presas casadas entre si, em união estável ou em relação homoafetiva", contemplando também a população carcerária LGBT. (DEPEN, 2018).

Gadelha (2016) relata que uma das reflexões do livro - "presos que menstruam" - é que o livro enseja sobre a discrepância das visitas íntimas, em relação aos presídios masculinos: nos femininos, muitas vezes as visitas são dificultadas, pois suas consequências podem ser mais dispendiosas ao Estado. Como declarou Heidi Cerneka, ativista da pastoral carcerária, "a mulher pode visitar seu marido, engravidar dentro da cadeia e sair: o problema é dela. Se a mulher está presa, o homem a visita e ela engravida: o problema é do Estado".

\subsection{A SITUAÇÃO ESPECÍFICA DA GESTANTE NO CÁRCERE}

O ser humano, desde o seu nascimento até o último dia de sua vida, ou seja, até a sua morte, necessita de acolhimento de seus responsáveis bem como de cuidados essenciais para a sua sobrevivência.

A Constituição Federal de 1988 apresenta em seu artigo 227, expressamente a obrigação da família de garantir à criança e ao adolescente de forma eficaz o direito à vida, ao lazer, à saúde, à alimentação, à educação, entre outros. Majora ainda, mais adiante, em seu artigo 229, ser dever incondicional dos pais assessorar, criar e educar os filhos menores e que os filhos deverão amparar seus pais na velhice. Jovem, de baixa renda, em geral mãe, presa provisória suspeita de crime relacionado ao tráfico de drogas ou contra o patrimônio; e, em menor proporção, condenadas por crimes dessa natureza - este é o perfil da maioria das mulheres em situação prisional no Brasil, inclusive das grávidas e puérperas aquelas com crianças de zero a seis meses - que estão encarceradas nas unidades femininas. (BRASIL, 2015).

Gadelha (2016) elucida que se estima que $85 \%$ das mulheres encarceradas são mães. Muitas chegam a dar à luz na cadeia. A lei permite que os "filhos do cárcere" vivam seis meses com a mãe, enquanto são amamentados, mas ativistas têm sugerido que as mães de bebês de até um ano deveriam ficar em prisão domiciliar durante a amamentação, tendo em vista que a cadeia não é de forma alguma um ambiente saudável para um recém-nascido.

Em alguns presídios a assistência à saúde da mulher gestante é inexistente, aumentando o risco de adoecerem por não obterem assistência devida; somado a isso está o fato de a maioria delas possuírem histórico de deficiência do acesso às ações de saúde, por se originarem de uma baixa 
condição socioeconômica, tornando-se este um problema de saúde pública (GALVÃO, DAVIM, 2013 apud MOREIRA et al., 2018).

Foi recorrente entre as mães presas ouvidas pela pesquisa "Dar á luz a sombra" o relato de que a juíza/juiz criminal não perguntou sobre a gravidez ou sobre as filhas e filhos da ré - a fala de uma delas ao responder se a juíza do caso não tinha notado a sua gestação avançada, é um retrato contundente: "ela nem olhou pra mim, quanto mais pra minha barriga". Da mesma forma, nenhuma detenta com as quais conversaram tinha informações precisas de seu processo relativo à guarda e a grande maioria relatou que nunca foram intimadas e/ou levadas para audiências cíveis enquanto estavam na prisão. (BRASIL, 2015).

Para mudar essa realidade, Souza (2018) elucida que em dezembro de 2010, a 65a Assembleia Geral da ONU aprovou as Regras Mínimas para as Mulheres Presas, as chamadas Regras de Bangkok, que trazem orientações acerca do tratamento das mulheres presas, além de buscar alternativas para as penas privativas de liberdade, levando em consideração as peculiaridades femininas, como a gravidez e o convívio com filhos.

Em 2011, a Assembleia Geral, através da Resolução 65/229, aprovou as Regras das Nações Unidas para o Tratamento de Prisioneiras Mulheres e medidas não privativas de liberdade para Mulheres Delinquentes (Regras de Bangkok), que estabeleceu normas que se relacionam especificamente para mulheres na prisão, infratoras e pessoas acusadas. As Regras de Bangkok reconhecem que o direito internacional, através do princípio da não discriminação, exige que os Estados abordem o particular desafio que as mulheres enfrentam na justiça criminal e nos sistemas penitenciários. Criaram normas abrangentes para o tratamento de mulheres prisioneiros e criminosas, abordando questões como a vitimização prévia e sua ligação com o encarceramento; alternativas ao encarceramento; física e mental, assistência médica; proteção e segurança; como manter contato com os membros da família; treinamento de pessoal; mulheres grávidas e mães com filhos na prisão; e a reabilitação e reintegração, entre outras medidas. (REGRAS DE BANGKOK, 2013, p.24 apud MARANHÃO; GIMENES, 2018).

Dentre as linhas que compõem uma crítica sobre a relação entre a capacidade estrutural das prisões e a disposição de asseverar os direitos fundamentais da mulher encarcerada, depara-se com a questão do exercício da maternidade no recinto carcerário. Nesse sentido, são contemplados pelo levantamento os dados relativos à existência de celas adequadas para gestantes, além da existência de berçário, creche e centro de referência materno-infantil. Somente 55 locais em todo o país declararam oferecer cela ou dormitório para grávidas. (DEPEN, 2017).

Segundo a Lei de Execução Penal 7.210, de 11 de julho de 1984, é assegurado à mulher encarcerada o acompanhamento médico, inclusive e principalmente quando ela se encontra em período gravídico. 
O art. 88 garante o direito dessas mulheres a uma seção específica para gestantes e parturientes e creches para abrigar crianças maiores de 6 (seis) meses e menores de 7 (sete) anos. (BRASIL, 2014 apud MOREIRA et al., 2018).

Souza (2018) explica que no caso da mulher gestante e lactante, a Constituição assegura que tenham direito a amamentar e continuar com seus filhos de forma digna, visto que a pena não pode passar da pessoa do apenado para terceiros e, portanto, seus filhos não poderiam ser atingidos pelo cumprimento de pena de suas mães, conforme artigo 5ำ L da Constituição Federal (1988), que diz que: $L$ - às presidiárias serão asseguradas condições para que possam permanecer com seus filhos durante o período de amamentação.

Na realidade do nosso país vemos que esses direitos tendem a não ser cumpridos como deveriam, fato este que é comprovado quando nos deparamos com unidades prisionais que apresentam falta de estrutura física, mobiliário insuficiente, muitas vezes precário, e falta de profissionais treinados e preparados para lidar com a saúde das gestantes. (CARNEIRO, VERÍSSIMO, 2016 apud MOREIRA et al., 2018).

Wolff e Moraes (2010) esclarece que exemplo dessa situação é a Lei 10.792/2003, que alterou o art. 52 da LEP, estabelecendo o Regime Disciplinar Diferenciado (RDD), o qual, contudo, não contemplou a situação das mulheres. No caso, tal regime estabelece isolamento severo de até 360 dias, o que lhe dificulta ou impede o contato com os filhos e família.

No estudo "Dar à luz a sombra" retrata que a subjetividade da presa é reduzida ao seu crime e o interrogatório é seu único momento de fala, uma fala pautada, engasgada, limitada ao que lhe foi perguntado. Da mesma maneira, à juíza/juiz da infância não interessa a situação processual da presa, o tempo de pena da condenada, ou quanto tempo falta para os benefícios de mudança de regime. (BRASIL, 2015).

Há uma ausência de escuta da mulher acerca de seus desejos e suas possibilidades. A categoria criminosa basta para deslegitimar a presa como boa mãe, logo, a decisão não leva em conta o contexto específico daquela mulher ao blindar suas possibilidades de exercício da maternidade. (BRASIL, 2015).

\subsection{A PRISÃO DOMICILIAR PARA AS MÃES}

O aprisionamento feminino traz uma questão importantíssima, que deve ser preocupação central das gestoras do sistema e idealizadoras de políticas prisionais: a população invisível que habita o nosso 
sistema prisional, as filhas e filhos de presas que vivem nas mais diversas e adversas condições nas prisões brasileiras. (BRASIL, 2015).

A sobrevivência, com dignidade, de uma criança depende de alimentação, cuidados, assistência material e afetiva. Para tanto, é necessário, com a máxima urgência, elaborar e implementar políticas que tratem da permanência do bebê com a mãe, que privilegiem o desencarceramento e, em casos de manutenção da prisão, que esta convivência se dê em ambiente confortável e salubre para ambas as partes, com recursos e suporte para a garantia dos direitos dessas mulheres e crianças. (BRASIL, 2015)

Castro (2017) elucida que na maioria dos estados brasileiros, a mulher grávida é transferida no terceiro trimestre de gestação de sua prisão de origem para unidades prisionais que abriguem mães com seus filhos, geralmente localizadas nas capitais e regiões metropolitanas. Essas mulheres são levadas ao hospital público para o parto e retornam à mesma unidade onde permanecem com seus filhos por um período que varia de seis meses a seis anos: a maioria entre seis meses e um ano. Depois desse período, geralmente as crianças são entregues aos familiares maternos/paternos, ou, na ausência destes, vão para abrigos e a mãe retorna à prisão de origem.

\subsubsection{LEIS, DECRETOS E DIREITOS DAS GESTANTES E MÃES NO CÁRCERE}

A Lei 11.942, de 2009 discorre sobre o direito das presas gestantes e parturientes a um local próprio para elas, assim como uma creche para abrigar crianças maiores de 6 (seis) meses e menores de 7 (sete) anos, para que possam cuidar melhor de si e de seu bebê. Assegura também às mães presas e aos recém-nascidos condições mínimas de assistência, como acompanhamento médico no período pré-natal e no pós-parto, assim como o atendimento ao recém-nascido. (MOREIRA, et. al., 2018).

No plano internacional, em dezembro de 2010, a Assembleia Geral da Organização das Nações Unidas (ONU) aprovou as regras mínimas para tratamento da mulher presa e medidas não privativas de liberdade para as mulheres em conflito com a lei, as chamadas Regras de Bangkok. (BRASIL, 2015).

Já no âmbito nacional, houve recentemente três importantes modificações legislativas, no sentido de garantir o exercício de maternidade pela reclusa: a Lei no 12.962/14, que regula sobre o convívio entre pais em situação de prisão e suas filhas e filhos, a Lei no 11.942/09, que assegura às mães reclusas e aos recém-nascidos condições mínimas de assistência exercício da maternidade, e, por fim, a Lei no $12.403 / 11$, que estendeu às gestantes e mães o direito à prisão domiciliar em substituição à prisão preventiva. (BRASIL, 2015). 
Ainda, tivemos a importante Resolução no 3 do Conselho de Política Criminal e Penitenciária (CNPCP) de 15 de julho de 2009, que disciplina a situação de filhas e filhos de mulheres encarceradas e institui o prazo mínimo de um ano e seis meses para que suas crianças permaneçam consigo. (BRASIL, 2015).

A Lei 13.257/2016 assegura que a prisão preventiva poderá ser substituída pela domiciliar, quando gestante, ou quando mãe de filhos de até 12 anos; antes a concessão era apenas para gestantes a partir do 7ํ (sétimo) mês (BRASIL, 2016 apud MOREIRA et. al., 2018).

O projeto de Lei é o $10.269 / 2018$, de autoria da senadora Simone Tebet (PMDB/MS), que foi sancionado e transformado na Lei 13.769, de 19 de dezembro de 2018. O propósito a lei é a substituição da prisão preventiva por prisão domiciliar da mulher gestante ou que for mãe ou responsável por crianças ou pessoas com deficiência, além de disciplinar o regime de cumprimento de pena privativa de liberdade de condenadas na mesma situação. (D’ÁVILA, 2018).

A autora citada reforça que a nova lei se sobrepõe em dois períodos: para mulheres que já se deparam em realização de pena e para estas que apresentaram cárcere preventivo estabelecido, isto é, que ainda não foram condenadas e estão respondendo ao processo penal.

A dificuldade em saber, ao certo, quantas mulheres se enquadram na lei retrata também a dificuldade de garantir esse direito. A nova lei traz mais uma possibilidade para sua aplicação por facilitar a identificação dessas mulheres por meio dos critérios objetivos. (D'ÁVILA, 2018).

Vale dizer que, após diversos casos de abuso de autoridades policiais e humilhações sofridas, o Presidente Michel Temer promulgou, no dia 27 de setembro do ano de 2016 o Decreto 8.858/16, que determina a proibição do uso de algemas durante o trabalho de parto e o período subsequente de sua internação em estabelecimento de saúde, permitindo seu uso restritivamente a situações de risco de fuga ou de perigo à integridade física do preso ou de terceiros.

Figura 1 - Quantas mulheres têm direito a Lei 13769/18?

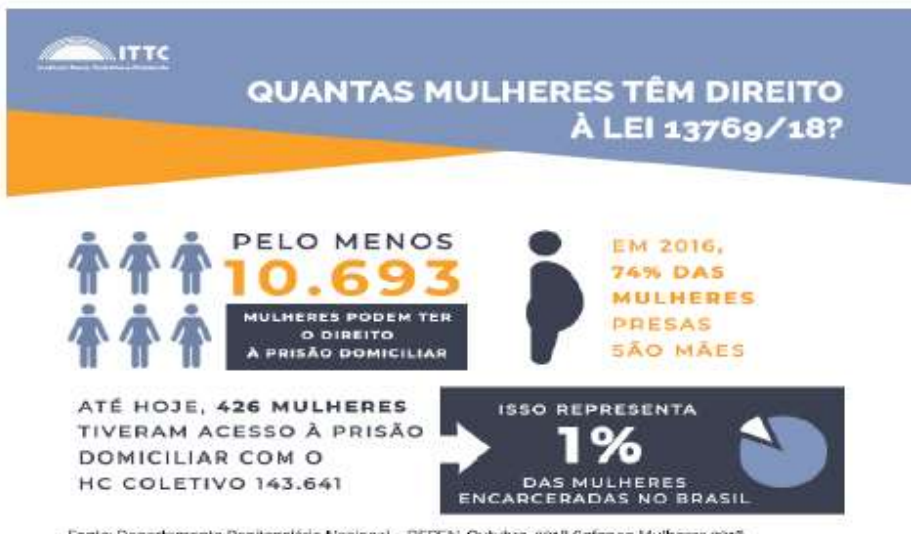


Faz-se necessário lembrar que é danosa a lei 13769/18, de acordo com D’Ávila (2018) três requisitos: a comprovação de não integração a organização criminosa, a constatação da primariedade; e a comprovação de apropriada conduta correcional pelos dirigentes do local.

De acordo com as mulheres que foram concedidas o habeas corpus tem os seguintes dados:

No que diz respeito às mulheres mães e gestantes presas provisoriamente, recentemente, o Departamento Penitenciário Nacional - DEPEN informou ao STF que havia 10.693 mulheres que seriam, em princípio, elegíveis para a concessão da prisão domiciliar, no termos do que foi decidido no habeas corpus coletivo. Entretanto, apenas 426 mulheres tiveram a prisão domiciliar concedida até então, o que equivale a cerca de $4 \%$ do total. Ainda, esse número representa $1 \%$ do total de mulheres encarceradas no Brasil, que é de 42.355 , e cerca de $2,2 \%$ do total de presas provisórias no Brasil, que são 19.223. (D'ÁVILA, 2018).

De acordo com a autora, a condição de a mulher ser primária, isto é, jamais ser decretada condenada na justiça antes, é um critério que não permanece sequer para que mulheres punidas a delitos hediondos precisem avançar de regime. Segundo a autora, essa previsão legislativa é inconstitucional, pois significa uma dupla punição por um dolo que já teve sua pena exercida. O propósito do Marco Legal da Primeira Infância é justamente impedir que a pena se estenda até os filhos, e essa condição estende, inclusive, a pena de um crime anterior.

Sobre a Lei $n$ o 13.769/2018 e a decisão do STF (habeas corpus 143.641) demonstram as preocupações dos Poderes Executivo, Legislativo e Judiciário sobre o agravamento do cenário do encarceramento de mulheres no Brasil, que chegou à marca de 42.355 em 2016 (Infopen Mulheres 2016), com crescimento de 656\% entre 2000 e 2016, bem como considera o melhor interesse das crianças, cumprindo com o disposto no Estatuto da Criança e do Adolescente e na Convenção sobre Direitos das Pessoas com Deficiências, filhas de mulheres privadas de liberdade, garantindo a convivência mãefilho, o aleitamento materno e o desenvolvimento biopsicossocial pleno. (DEPEN, 2018).

De acordo D’Ávila (2018) com a inexistência de qualquer tipo de documentação que comprove a produção de prova de não filiação a organização criminosa, é inadequada e discriminatória impô-la a indivíduas mães e gestantes, já que tal episódio, ainda mais ponderando o precário acesso à justiça, trata-se de uma condição inexistente na legislação.

Isso torna a lei inócua, além de ter potencial de criar precedentes altamente prejudiciais a mulheres selecionadas pelo sistema penal. Atualmente, $62 \%$ das mulheres privadas de liberdade foram condenadas ou aguardam julgamento por crimes ligados ao tráfico de drogas, que em geral são praticados como atividade de subsistência e não por figuras integrantes de organização criminosa. (D'ÁVILA,2018). 
Por fim, a exigência de comprovação de bom comportamento carcerário também constitui ônus que não deve ser atribuído às próprias mulheres. O relatório feito pelo diretor ou diretora do estabelecimento já é previsto na Lei de Execução Penal para a progressão de regime. Acrescentar essa exigência permite o entendimento de que é necessária a produção de um novo relatório baseado na condição de mãe ou gestante das mulheres, aumentando as chances de negativas e arbitrariedades. (D’ÁVILA, 2018).

A primeira pesquisa nacional realizada nas capitais dos estados brasileiras identificou aproximadamente 400 crianças vivendo com suas mães no cárcere, sendo 370 com menos de um ano de idade (LEAL et al., 2016 apud SIMAS; BATISTA; VENTURA, 2018 ).

Em levantamento para instituir o Cadastro Nacional de Presas Grávidas e Lactantes, o Conselho Nacional de Justiça divulgou que, em 2017, havia 373 mulheres grávidas e 249 amamentando seu filho no sistema penitenciário (CNJ, 2018).

Segundo Stella (2001) as possibilidades de guarda, para os filhos de mulheres presas, fazem emergir um conflito básico entre o direito da criança ao convívio familiar e as funções básicas de punição e isolamento da prisão. No plano jurídico, reserva-se ao termo guarda uma conotação específica, adquirida na área da legislação sobre infância e adolescência, que obriga os guardiães à prestação de assistência material, moral e educacional à criança ou adolescente, conferindo-lhes o direito de oporse a terceiros, inclusive aos pais no art. 33 do ECA.

Simas; Batista; Ventura, (2018) esclarece que os cuidados com a saúde sexual e reprodutiva, programas e ações públicas de apoio à maternidade e às famílias são negligenciados pelo Estado. Em geral, o acesso à saúde possui sérias limitações; as mulheres têm sua vulnerabilidade aumentada em razão de obstruções ao acesso a serviços de saúde, jurídicos e sociais, além das degradantes condições ambientais carcerárias. Essa situação é estendida aos seus filhos, reproduzindo um círculo vicioso de persistente desrespeito.

Os autores citados acima afirmam que a tentativa de invisibilizar essas crianças, que já nascem e crescem "presas" nos muros do cárcere, conjuga-se com a retirada posterior de forma abrupta do convívio com sua mãe, sem amparo social adequado. Entre os vários dilemas que envolvem as mães presas, a dúvida é em saber como e com quem esses filhos ficarão durante o aprisionamento da genitora, inclusive porque caberia a esse cuidador manter o vínculo mãe-bebê através de visitações periódicas e regulares, o que não ocorre com frequência. 
A prisão preventiva é medida excepcional de acordo com a legislação nacional e internacional, e no caso das mulheres grávidas e/ou com filhos, a aplicação de medidas desencarceradoras atende à melhor proteção dos direitos humanos desses segmentos. (SIMAS; BATISTA; VENTURA, 2018).

Reconhecem que uma parcela dessas mulheres não representa risco à sociedade, e seu encarceramento pode dificultar sua reinserção social, bem como incentivam Estados a adotar legislações para estabelecer alternativas à prisão e a priorizarem o financiamento de tais sistemas. (SIMAS; BATISTA; VENTURA, 2018).

O afastamento da vivência comunitária e familiar é somente um dos problemas da infância aprisionada. Os relatos das internas atendidas pelo Projeto Mulheres pelas Mulheres e, também, das próprias agentes demonstram que muitas crianças acabam internalizando a lógica disciplinar inerente a uma prisão. (SÁ; SIMÕES; BARTOLOMEU, 2019).

As autoras supracitadas explicam que o ato de abaixar a cabeça e colocar as mãozinhas para trás enquanto as agentes passam, assim como as "brincadeiras" da revista corporal, de "sair de alvará" ou de "esperar o advogado" fazem eclodir os efeitos simbólicos que a realidade prisional pode gerar no desenvolvimento das crianças. Efeitos que podem se traduzir, inclusive, numa transgeracionalidade em torno do ambiente prisional.

Segundo apuração do DEPEN (2018) junto aos órgãos estaduais de administração penitenciária, entre fevereiro e novembro de 2018, 2.895 mulheres tiveram as prisões preventivas substituídas pela domiciliar, atendendo a ordem do STF. Mesmo assim, tal quantitativo é subdimensionado, haja vista a dificuldade dos órgãos estaduais em realizarem o levantamento específico, bem como das dificuldades de os judiciários dos estados cumprirem com a determinação.

O suporte fático para a concessão da ordem consistiu na comprovação de que mulheres grávidas e mães de crianças (compreendidas no sentido legal conferido pelo art. 2o do ECA: até doze anos incompletos) estavam sendo submetidas a prisões preventivas em situação degradante, não dispunham de cuidados médicos pré-natais e pós-parto e não contavam com berçários e creches para seus filhos. (CUNHA, 2019)

Em razão disso, determinou-se "a substituição da prisão preventiva pela domiciliar - sem prejuízo da aplicação concomitante das medidas alternativas previstas no art. 319 do CPP - de todas as mulheres presas, gestantes, puérperas ou mães de crianças e deficientes, nos termos do art. 2o do ECA e da Convenção sobre Direitos das Pessoas com Deficiências (Decreto Legislativo 186/2008 e Lei 
13.146/2015), relacionadas neste processo pelo DEPEN e outras autoridades estaduais, enquanto perdurar tal condição, excetuados os casos de crimes praticados por elas mediante violência ou grave ameaça, contra seus descendentes ou, ainda, em situações excepcionalíssimas, as quais deverão ser devidamente fundamentadas pelo juízes que denegarem o benefício". (CUNHA, 2019)

E estendeu-se a ordem de ofício a todas as demais presas gestantes, puérperas ou mães de crianças e de pessoas com deficiência, assim como às adolescentes sujeitas a medidas socioeducativas que estivessem na mesma situação daquelas beneficiadas diretamente pela impetração. (CUNHA, 2019)

Cunha (2019) explica que, no final do ano 2018, a Lei 13.769/18 alterou a legislação processual penal para disciplinar a matéria de forma expressa. Para tanto, inseriram-se no Código de Processo Penal os artigos 318-A e 318-B.

O autor citado esclarece que o art. 318-A estabelece que a prisão preventiva decretada sobre a "mulher gestante ou que for mãe ou responsável por crianças ou pessoas com deficiência será substituída por prisão domiciliar", desde que a presa: I - não tenha cometido crime com violência ou grave ameaça a pessoa; II - não tenha cometido o crime contra seu filho ou dependente. Já o art. 318B dispõe que a substituição da prisão preventiva pela domiciliar pode ser efetuada com aplicação concomitante das medidas alternativas previstas no art. 319.

\section{PRISÃO DOMICILIAR / PENA}

\section{LEGISLAÇÃO GARANTIA}

\section{CONSIDERAÇÕES FINAIS}

Mediante o exposto, evidencia-se que o presente estudo teve como principal assunto uma abordagem sobre as mulheres no cárcere e suas variáveis como a gravidez, a maternidade e os seus direitos na prisão domiciliar. Tratando-se de uma revisão bibliográfica.

No primeiro momento discorreu sobre a proteção constitucional da maternidade; a licença maternidade antes e após a constituinte de 1988; e por último, a proteção constitucional à maternidade na atualidade. Nota-se que mudanças significativas ocorreram neste período, porque há poucos anos a mulher era apreciada somente dona do lar, protetora de seus filhos e dependentes de seus maridos. Mas isso modificou. E na constituição os seus direitos também foram progredindo. 
Nesse sentido, inúmeras ativistas feministas asseguram que de acordo com a história, na cultura brasileira, existiu sempre a diversidade de direitos entre homens e mulheres, havendo um préjulgamento moral e legal que impediam as mulheres de praticarem estabelecidos cargos e desempenhar certos serviços.

Seguindo este raciocínio, o estudo mostrou que, de acordo com a história do trabalho da mulher no Brasil, consegue ser repartida em etapas ou épocas determinadas por marcos jurídico. Nesta primeira etapa, a mulher era eliminada do mundo do trabalho e limitada no lar perante a subjugação masculina, ou tinha uma parte econômica tutelada, este momento vai desde o ordenamento da República Velha (1891) até a revolução de 1930.

Continuando o raciocínio, a segunda fase começou com a liberdade legal e a salvaguarda do trabalho da mulher, este ciclo se inaugura com a Constituição de 1934 e, em particular a promulgação da CLT (1943), indo até o período de transformação aberto pela Nova República (1985).

Em virtude dos fatos mencionados e exemplificando, a terceira fase obedece à concretização dos direitos sociais, à evidência na equidade no trabalho e à maior efetividade da interpretação das mulheres como participantes sociais. Nesta fase parte da promulgação da Constituição Cidadã de 1988 e segue até os dias atuais.

No segundo momento, outro fator existente no estudo, foi sobre a realidade do Sistema Prisional Brasileiro. E foram abordados os direitos assegurados pela Lei de Execução Penal; mostradas as atuais condições dos presídios femininos o Brasil e logo em seguida discutiu o Estado de coisas inconstitucionais nas prisões.

Pelo exposto, primeiramente verificou-se que o sistema prisional está falido. Para alguns autores, se a pena privativa de liberdade é o meio selecionado pela sociedade para fazer com que os apenados pensem sobre sua atitude, de tal forma que eles procurem sempre aprimorar enquanto sujeito ao longo da execução da pena, mais há um contra censo nisso, pois na realidade, o que se caracteriza é uma real decepção, apresentando um número exagerado de condenados que concluiu a pena e não conseguem ter a integração na sociedade novamente, comprovando claramente que a pena de prisão não consegue cumprir com os fins aos quais se designa.

Como se averiguou, em se tratando de penitenciárias femininas, que são poucas, é o que foi mostrado nos estudos, às condições são precárias. A superlotação, a falta de condições sanitárias, a ausência de creches para os filhos das mães detentas são alguns dessas condições. 
Tendo em vista os aspectos observados, muitos autores discorrem que há uma urgência nas modificações apropriadas e há a necessidade urgente de seguirem as indicações especiais, como as regras de Bangkok. Seguindo os inícios indicadores das Regras Mínimas das Nações Unidas para Elaboração de Medidas Não Privativas de Liberdade (Regras de Tóquio), as normas de Bangkok exibem como uma de suas ideias iniciais a consideração de que as mulheres presas têm carências e reivindicações específicas. É claro perceber as falhas na execução dessas leis.

E ficou evidente que, em relação às penitenciárias femininas brasileiras, apesar de haver contestações importantes entre elas, e sendo mais garantidoras de direitos, melhor equipadas e mais bem elaboradas que outras, podemos dizer que nenhuma delas funciona em respeito pleno aos parâmetros legais atuais, considerando aqui as regras de Bangkok e a Lei no 7.210/84 - Lei de Execução Penal Brasileira (LEP).

Ficou claro no estudo também que o tratamento que as presas recebem na penitenciária não é nada justo para recuperar um indivíduo, são humilhadas, maltratadas, independente de qual delito tenha feito, seus benefícios ínfimos são ignorados. O direito à educação e ao trabalho não é assegurado a todas as presas, o que dificulta a garantia legal de quitação da pena por estudo e não há divisão de unidades entre detentas condenadas e provisórias.

O terceiro capítulo trouxe um tema polêmico e sugestivo a muitas discussões, a maternidade no cárcere e a prisão domiciliar. Foram apresentadas as situações das mulheres no cárcere, as condições das gestantes e os direitos e deveres da prisão domiciliar para essas mães.

É absolutamente prioritário destacar que foi compreensível através do estudo entender que, para a maioria dos autores, o sistema prisional não foi construído para acolher mulheres gestantes, muito menos bebês, por se tratar de um lugar exclusivo com normas de comportamentos, condutas decretadas e, acima de tudo, por ter particularidades de um ambiente tenso e violento, tornando-se um lugar hostil para a gravidez. Muitos bebês vivem com suas mães em celas superlotadas, úmidas, fétidas, chegando a dormir no chão.

De acordo com o citado acima é importante frisar que, diante da importunidade dos ambientes prisionais, a aplicação de medidas alternadas à prisão representa uma maior preservação e segurança aos direitos maternos e infantis. A maioria das instituições prisionais, ainda que possua formalmente recinto designado como creche, não está adaptada às necessidades femininas e infantis. 
Em se tratando da proibição do uso das algemas no momento do parto, diferentes estudiosos e pessoas de notável saber jurídico da sociedade apontam que, apesar das medidas sobre esta interdição nos deixem com a esperança de que a decência dessas mulheres seja acatada independentemente do crime cometido, o que se evidencia é um vagaroso avanço para o entendimento de que o uso delas não é apenas impróprio e vexativo, é uma forma de tortura para com estas presidiárias. E aqueles que cometem em métodos de tortura e de abuso devem ser punidos, para garantir, verdadeiramente, o amparo à dignidade, segurança e saúde da mulher.

Após a efetivação do estudo, evidencia-se que a hipótese da pesquisa confirmouse já que os direitos das detentas grávidas e mães nos presídios não são respeitados no Brasil.

Afirmando o que os autores discorrem sobre os direitos das detentas grávidas e mães nos presídios e afirmam que há muito a esclarecer sobre esses direitos e que muitas vezes são negados as detentas.

Ressalta-se ainda que os objetivos específicos traçados para este estudo foram alcançados, sendo que, em um primeiro momento foi apresentado à historicidade da proteção constitucional da maternidade e também na atualidade, foi descrito sobre a realidade do sistema prisional, e por fim foi discutido sobre a gravidez e maternidade no cárcere e a prisão domiciliar.

O tema proposto é de grande importância, tendo em vista que nós, enquanto estudantes de Direito, devemos estar sempre preocupados com a ineficiência da pena privativa de liberdade. Principalmente nas prisões femininas, onde deparamos com maiores violações no tocante ao exercício de direitos de forma geral, e em especial dos direitos sexuais e reprodutivos, bem como de entrada à saúde especializada.

Compete a nós, ainda, gerarmos discussões acerca do tema para que possamos, na medida do possível, modificar o pensamento e o costume das pessoas que, muitas vezes, creem intensamente que isolar o indivíduo transgressor em uma cela é a única maneira de eliminar a violência de nosso país.

Sobre as múltiplas declarações em obras que têm sido recolhidos ao longo da história, evidenciando em palavras e em cenas como é a debilidade oferecida às mulheres grávidas e as que vivem com seus bebês dentro do sistema prisional, deixo aqui uma dos momentos importantes que marcou neste estudo, em uma fala sobre uma das detentas que, conforme a autora da obra Nana Queiroz expõe, ganhou no grito o direito de ir ao hospital e ficou algemada à cama durante boa parte do trabalho de parto: "Entre uma contração e outra, ela foi observando a rua, as pessoas que olhavam o carro com 
medo, com curiosidade, com hipocrisia. A ninguém importava Gardênia ou o bebê que carregava. Eles eram o resto do prato daquela sociedade. O que ninguém quis comer. E seu filho já nascia como sobra". Fica a reflexão.

Sobre a problemática deste estudo, conclui-se, que a dignidade humana e a cidadania são dois dos fundamentos da República Federativa do Brasil, previstos no art. 1ำ da Constituição Federal Brasileira de 1988. E se faz necessário que o Poder Público apresente para os indivíduos meios para que estes direitos sejam efetivados e aplicados. O Poder

Judiciário, o Ministério Público, a Defensoria Pública, a Ordem dos Advogados do Brasil e as Procuradorias têm vital importância para a sociedade justamente por atuarem diretamente com as demandas jurídicas e, dentre as diversas funções desenvolvidas, garantir os direitos.

Nota-se no estudo que a legislação brasileira elenca distintas regras propostas ao amparo da mulher gestante. E que um dos desígnios deste conjunto de leis é exatamente a proteção da integridade física e mental das mulheres gestantes, só que a circunstância se torna patética quando a grávida se depara em reclusão, cumprindo pena privativa de liberdade.

Ademais, o feto é o principal lesado pela deficiência de auxílio médico adequado nesta fase.

O princípio da impessoalidade da pena está consagrado no artigo 5o, inciso XLV, da CRFB/88, que determina que "nenhuma pessoa passará da pessoa do condenado". Este princípio garante que apenas quem agiu no crime será por ele culpado, não competindo à privação de liberdade para quem não concorreu ao tipo penal. A criança, que não cometeu o hipotético delito, é privada de liberdade juntamente com sua mãe, atribuindo a ela uma pena que não lhe cabe: a de viver em um ambiente insalubre, sem atenção aos seus direitos e garantias fundamentais.

É garantido a todas as mulheres o tratamento humano e digno no acompanhamento da gestação, no parto e no pós-parto. Mas a prisão preventiva, ao encarcerar mulheres grávidas em unidades prisionais precárias, impede-lhes o acesso a programas de saúde pré-natal, assistência regular na gestação e no pós-parto.

E neste sentido, coíbe as crianças de condições apropriadas ao seu pleno e sadio desenvolvimento, compondo assim tratamento degradante, desumano e cruel e, o que transgrede os códigos constitucionais relacionados à vedação de penas cruéis, à individualização da pena, e, ainda, ao respeito à integridade física e à probidade moral da encarcerada. 
Conclui-se, por conseguinte, que as narrativas acima descritas infringem os princípios legais, constitucionais e internacionais referentes aos direitos das carcerárias e de seus filhos. São indiscutíveis e evidentes as implicações nefastas da prisão da mulher e da posterior ruptura abrupta de seus filhos, no bem-estar físico e psíquico dos mesmos. 


\section{REFERÊNCIAS}

ANDRADE, Andressa Paula de. CAMBI, Eduardo. Encarceramento da maternidade no estado de coisas inconstitucional. Revista Brasileira de Ciências Criminais, vol. 160. São Paulo: Ed. RT, 2019. Disponível em: https://www.revistadostribunais.com.br. Acesso em: 20 ago. 2019.

ANGOTTI, Bruna Soares. Entre as leis da ciência, do Estado e de Deus: o surgimento dos presídios femininos no Brasil. Comentários de José Daniel Cesano. 2a ed. revisada. San

Miguel de Tucumán: Universidade Nacional de Tucumán. Instituto de Investigações Históricas Leoni Pinto, 2018. Disponível em: http://carceraria.org.br/wpcontent/ uploads/2018/06/bruna-angottientre-as-leis-da-ciencia-do-estado-e-de-deus.pdf.Acesso em: 19 jan. 2019.

BATISTA, Wellington da Rocha. Sistema prisional brasileiro à luz do princípio da dignidade da pessoa humana e da lei de execução penal. 2017. Disponível em:

www.facnopar.com.br/.../arquivo-2017-06-14-14974682133082.pdf. Acesso em: 10 ago. 2019.

BUSATO, Paulo César; CAVAGNARI, Rodrigo. Reserva de lei e execução penal: quando a jurisprudência benéfica prima facie se volta contra o condenado. Revista Brasileira de Ciências Criminais, vol. 150, p. 235 - 255, dez. São Paulo: ed. RT, 2018. Disponível em:

https://www.revistadostribunais.com.br. Acesso em: 25 ago. 2019.

BRAGA, Ana Gabriela et al. Guardiões de castelos de areia: um retrato dos serviços prisionais do Nordeste Brasileiro. Revista Brasileira de Ciências Criminais, vol. 145, p. 25-63, jul. São Paulo: Ed. RT, 2018. Disponível em: https://www.revistadostribunais.com.br. Acesso em 19 ago. 2019.

BRASIL, Ministério da Justiça. Departamento Penitenciário Nacional (DEPEN). Sistema

Nacional de Informação Penitenciária. Relatório nacional sobre a população penitenciária feminina do País, Brasília, junho, 2014. Disponível em:

http://www.justica.gov.br/noticias/estudo-traca-perfil-da-populacao-penitenciaria-femininanobrasil/relatório. Acesso em 12 out. 2019.

. Ministério da Justiça. Secretaria de Assuntos Legislativos. Dar à luz na sombra: condições atuais e possibilidades futuras para o exercício da maternidade por mulheres em situação de prisão. Brasília: Ministério da Justiça, IPEA, 2015. p. 92. Série Pensando o

Direito, 51. Disponível em: http://carceraria.org.br/wp-content/uploads/2018/01/documentodar- aluz-na-sombra.pdf. Acesso em: 19 jan. 2019.

Conselho Nacional de Justiça. Regras de Bangkok. Regras das nações unidas para o tratamento de mulheres presas e medidas não privativas de liberdade para mulheres infratoras. Série tratados internacionais de direitos humanos. Brasília, 2016. Disponível em:

http://www.cnj.jus.br/files/conteudo/arquivo/2016/03/27fa43cd9998bf5b43aa2cb3e0f53c44.pdf.

Acesso em: 20 jan. 2019. 
CARDONE, Marly A. A mulher nas Constituições Brasileiras. Doutrinas Essenciais de Direitos Humanos, vol. 4, p. 449 - 480, ago. 2011. Disponível em:

https://www.revistadostribunais.com.br. Acesso em: 12 maio 2019.

CASTRO, Regina. Nascer nas prisões: gestação e parto atrás das grades no Brasil. 2017.

Disponível em:

https://portal.fiocruz.br/noticia/nascer-nas-prisoes-gestacao-e-parto-atras-dasgrades-no-brasil. Acesso em: 23 out. 2019.

CAVALCANTE, Diego Lopes. Estado de coisas inconstitucional diante das inovações da jurisdição constitucional. Revista de Direito Constitucional e Internacional, vol. 104, p. 37 - 63, nov - dez. São Paulo: Ed. RT, 2017. Disponível em:

https://www.revistadostribunais.com.br. Acesso em 25 ago. 2019.

CONSELHO NACIONAL DE JUSTIÇA. CNJ. Brasil tem 622 grávidas ou lactantes em presídios. 2018. Disponível em: www.cnj.jus.br/noticias/cnj/86062-brasil-tem-622-gravidasou- lactantes-empresidios. Acesso em: 31 mar. 2019.

CUNHA, Rogério Sanches. 647: Execução da pena e prisão domiciliar para condenadas. 2019.

Disponível em:

https://meusitejuridico.editorajuspodivm.com.br/2019/05/28/647-e-possivelconcessao-de-prisaodomiciliar-para-condenada-com-filho-menor-de-12-anos-ou-responsavel-porpessoa-comdeficiencia/. Acesso em: 12 out. 2019.

D’ÁVILA, Maria Clara. Aprovado projeto de lei que garante prisão domiciliar para mães e Gestantes. Instituto Terra, Trabalho e Cidadania - ITTC. 2018. Disponível em:

http://ittc.org.br/aprovado-lei-13769-prisao-domiciliar/. Acesso em 23 out. 2019.

DEPARTAMENTO PENITENCIÁRIO NACIONAL. DEPEN. Levantamento Nacional de Informações Penitenciárias. INFOPEN Mulheres. Org. Thandara Santos, Colab. Marlene Inês da Rosa...[et al.]. Brasília: Ministério da Justiça e Segurança Pública. Departamento

Penitenciário Nacional, 2017. Disponível em:

http://depen.gov.br/DEPEN/depen/sisdepen/infopen-mulheres/infopenmulheres_arte_07-0318.pdf. Acesso em: 19 jan. 2019.

Ministério da Justiça e Segurança Pública.Sancionada lei que substitui a prisão preventiva por domiciliar de mulheres com filhos até 12 anos. 2018. Disponível

em: http://depen.gov.br/DEPEN/sancionada-lei-que-substitui-a-prisao-preventiva-pordomiciliar-demulheres-com-filhos-ate-12-anos. Acesso m: 23 out. 2019. 
FONTELES, Samuel Sales. O Inconstitucional Estado de Coisas: ficção e realidade. Revista de Processo Comparado, vol. 7, jan a jun. p.253 - 279. São Paulo: Ed. RT, 2018. Disponível em: https://www.revistadostribunais.com.br. Acesso em: 24 ago. 2019.

GADELHA, Luísa. Presos que menstruam: a situação das mulheres nas prisões brasileiras.

2016. Disponível em:

https://www.diariodocentrodomundo.com.br/presas-que-menstruam-asituacao-das-mulheres-nasprisoes-brasileiras-por-luisa-gadelha. Acesso em: 19 jan. 2019.

GARCIA, Maria. Os direitos humanos da criança e a licença-maternidade: a interpretação constitucional e uma questão de linguagem. Revista de Direito Constitucional e Internacional, vol. 79/2012, p. 57 - 72, abr - jun / 2012. Disponível em:

<https://www.revistadostribunais.com.br >. Acesso em: 10 maio 2019.

GHISLENI, Pâmela Copetti. O sistema penitenciário brasileiro e o princípio da dignidade da pessoa humana. Direito em Debate. Revista do Departamento de Ciências Jurídicas e Sociais da Unijuí. Ano XXIII no 42, jul. dez. 2014. Disponível em:

https://www.revistas.unijui.edu.br/index.php/revistadireitoemdebate. Acesso em 16 ago. 2019.

LAZARI, Rafael de; PIRES, Hugo. Estado de coisas inconstitucional: um dilema judiciário da contemporaneidade. Revista de Direito Constitucional e Internacional, vol. 100, p. $103-116$, mar e abr. São Paulo: Ed. RT, 2017. Disponível em:

https://www.revistadostribunais.com.br. Acesso em 20 ago. 2019.

MARANHÃO, Douglas Bonaldi; GIMENES, Amanda Mendes. O encarceramento feminino no Brasil e a política legislativa brasileira em face das regras de Bangkok. Revista Brasileira de Ciências Criminais, vol. 147/2018, p. 219 - 249, set. 2018. DTR\2018\19320. Disponível em:

<https://www.revistadostribunais.com.br. Acesso em: 31 mar. 2019.

MARTINEZ, Luciano; NÓVOA, Juliana. O direito fundamental à proteção à maternidade nos âmbitos trabalhista e previdenciário. Revista dos Tribunais, vol. 1000, p. 515-531, fev. São Paulo: Ed. RT, 2019. Disponível em: <https://www.revistadostribunais.com.br/ >. Acesso em 08 maio 2019.

MIRABETE, Júlio Fabbrini; FABBRINI; Renato N. Execução Penal: comentários à Lei no 7.210 de 11/07/1984. São Paulo: Atlas, 2014.

MOREIRA, Rafaela Araújo et al. Com a palavra, as mulheres: maternidade por trás das grades. Revista Brasileira de Ciências Criminais. Vol. 146, ano 26. p. 649 - 662. São

Paulo: Ed: RT, 2018. Disponível em: https://www.revistadostribunais.com.br. Acesso em: 31 mar. 2019.

NASCIMENTO, Grasiele Augusta Ferreira. VILLAS BÔAS, Regina Vera. Proteção da mulher: direito individual e social à igualdade de condições no mercado de trabalho e ao direito à maternidade. 2015. III encontro de internacionalização do CONPEDI - 
MADRID. Disponível em:

http://www.portaltutor.com/index.php/conpedireview_old/article/view/127/0. Acesso em: 01 jun. 2019.

OLIVEIRA, George Felício Gomes de. A função do orçamento: direito social da proteção à maternidade e o PPA do município de Fortaleza (2014-2017). Revista de Direito

Constitucional e Internacional, vol. 97, p. 229 - 251, set - out. São Paulo: RT, 2016.

Disponível em: https://www.revistadostribunais.com.br. Acesso em 12 maio 2019.

OLIVEIRA, Francisco Antônio de; LOPES, Mauricio Antonio Ribeiro. O salário-maternidade e a emenda constitucional 20/1998 - limites ao poder constituinte derivado e interpretação da constituição segundo seus valores fundamentais. Revista de Direito do Trabalho, vol. 97,p. 68 - 79, jan - mar. 2000 Doutrinas Essenciais de Direito do Trabalho e da Seguridade Social, vol. 5, p. 887 - 900, set. São Paulo: RT, 2000. Disponível em:

https://www.revistadostribunais.com.br. Acesso em: 12 maio 2019.

PENTEADO, Franciéle Aparecida; MARGRAF, Priscila de Oliveira; RAZABONI JUNIOR, Ricardo Bispo. Aspectos da estabilidade provisória da gestante nos contratos de trabalho por tempo determinado e a proteção à maternidade. Revista de Direito do Trabalho, vol. 192, p. 59-78, ago. São Paulo: RT, 2018. Disponível em: https://www.revistadostribunais.com.br. Acesso em 12 maio 2019.

PRONI, Thaíssa Tamarindo da Rocha Wheishaupt. Proteção constitucional à maternidade no Brasil: um caso de expansão da garantia legal. 2012. Dissertação (Mestrado em Direito do Trabalho) - Faculdade de Direito, Universidade de São Paulo, São Paulo, 2012. Disponível

em: http://www.teses.usp.br/teses/disponiveis/2/2138/tde-30102012-101834/pt-br.php.Acesso em: 21 mar. de 2019.

QUEIROZ, Nana. Descubra como é a vida das mulheres nas penitenciárias brasileiras. 2015. Disponível em: https://revistagalileu.globo.com/Revista/noticia/2015/07/descubracomo-e-vida-das-mulheresnas-penitenciarias-brasileiras.html. Acesso em: 19 jan. 2019.

RONCHI, Isabela Zanette. A maternidade e o cárcere: uma análise de seus aspectos fundamentais. 2017. Disponível em:

http://www.pucrs.br/direito/wpcontent/uploads/sites/11/2018/03/isabela_ronchi_20172.pdf. Acesso em 24 set. 2019.

SÁ, Priscilla Placha; SIMÕES, Heloisa Vieira; BARTOLOMEU, Priscilla Conti. Quem te prende e não te solta: as regras de Bangkok e a análise de decisões denegatórias do poder judiciário do Estado do Paraná em pedidos de prisão domiciliar para mulheres presidiárias gestantes e com crianças. Revista Brasileira de Ciências Criminais, vol. 151/2019, p. 383 -416, jan, 2019. Disponível em:

<https://www.revistadostribunais.com.br/maf/app/resultList/document?\&src=rl\&srguid=iOad>. Acesso em: 31 mar. 2019. 
SANTOS, Marcel Ferreira dos; ÁVILA, Gustavo Noronha de. Encarceramento em massa e estado de exceção: o julgamento da Ação de Descumprimento de Preceito

Fundamental 347. Revista Brasileira de Ciências Criminais, vol. 136, ano 25. São Paulo: Ed. RT, 2017. Disponível em: https://www.revistadostribunais.com.br. Acesso em 12 maio 2019.

SIMAS, Luciana; BATISTA, Vera Malaguti; VENTURA, Miriam. Mulheres, maternidade e o sistema punitivo: limites e possibilidades das audiências de custódia no estado do rio de janeiro. Revista Brasileira de Ciências Criminais, vol. 149, p. 455 - 489, nov. São Paulo: RT, 2018. Disponível em: https://www.revistadostribunais.com.br. Acesso em: 31 mar. 2019.

SOUZA, Eduarda Almeida. A mulher no cárcere: uma análise do sistema prisional feminino no Brasil. 2018. Disponível em:

https://pantheon.ufrj.br/bitstream/11422/6130/1/EASouza.pdf. Acesso em: 26 set. 2019.

STELLA, Claudia. As implicações do aprisionamento materno na vida dos(as) filhos(as).

Revista Brasileira de Ciências Criminais, vol. 34/2001, p. 237 - 264, abr - jun. 2001,

DTR\2001\153. Disponível em:

<https://www.revistadostribunais.com.br/maf/app/resultList/document?\&src=rl\&srguid=i0ad>. Acesso em: 31 mar. 2019.

WOLFF, Maria Palma; MORAES, Márcia Elayne Berbich. Mulheres e tráfico de drogas: uma perspectiva de gênero. Revista Brasileira de Ciências Criminais, vol. 87, p. 375 - 395 nov - dez. Doutrinas Essenciais de Direitos Humanos, vol. 4, p. 429 - 448, ago. São Paulo: RT,

2011. https://www.revistadostribunais.com.br. Acesso em: 31 mar. 2019.

WORLD PRISON BRIEF. 2019. Disponível em:

https://www.prisonstudies.org/country/brazil. Acesso em: 25 ago. 2019. 